\title{
Pleistocene plateau ice fields in the High Atlas, Morocco
}

\author{
George Hannah $^{1,3}$, Philip D. Hughes ${ }^{2 *}$, Philip L. Gibbard ${ }^{3}$ \\ ${ }^{1}$ Cambridge Quaternary, Department of Earth Sciences, University of Cambridge, Cambridge CB2 3EQ, UK \\ ${ }^{2}$ School of Environment, Education and Development, The University of Manchester, Manchester M13 9PL, \\ UK \\ ${ }^{3}$ Cambridge Quaternary, Department of Geography, University of Cambridge, Cambridge CB2 3EN, UK
}

*Corresponding author. E-mail: philip.hughes@manchester.ac.uk

\begin{abstract}
:
Large ice fields $\left(>25 \mathrm{~km}^{2}\right)$ formed over the Tazaghart and Iouzagner plateaux of the High Atlas, Morocco, during the Late Pleistocene. The plateau ice fields were drained by large valley glaciers forming a series of moraine assemblages. Four moraine units have been mapped and subdivided on the basis of morphostratigraphy and the degree of soil weathering. Soil profile development index (PDI) values indicate that the moraine units are widely separated in time with the oldest moraines deeply weathered and degraded whereas soils are absent on the youngest moraines. The highest moraine unit was formed by a small niche glacier which was present as recently as the mid 20th Century. Pleistocene glaciers are likely to have been associated with wetter conditions than today in addition to colder air temperatures. Combined with ice in neighbouring areas, such as the Toubkal Massif, the SW High Atlas supported some of the largest glaciers in Africa during the Pleistocene. The extent of glaciation with ice exploiting and breaching drainage divides has major implications for landscape development. The evolution of the High Atlas is therefore strongly shaped by glaciation and this is closely intertwined with tectonic, fluvial and slope processes.
\end{abstract}

\section{Introduction}

The Atlas Mountains are the highest in North Africa and reach $4167 \mathrm{~m}$ a.s.l. at Jebel Toubkal in the Marrakech Atlas. One of the first recorded notes on the glacial geomorphology of the area was reported by Maw in Hooker and Ball (1878). In the same area Thompson (1899) also recognised that the area had been glaciated. Some of the earliest detailed notes were made by Célérier and Charton (1922) and De Martonne (1924) followed by Dresch (1941) who produced some sketch maps of the whole Toubkal massif depicting the suggested distribution of the former glaciers. Later studies by Heybrock (1953), Mensching (1953), Chardon and Riser (1981) and Hughes et al. (2004; 2011) all built on these earlier studies.

Despite the concentration of research in a relatively small area around the peaks of Toubkal (4167 m a.s.1.) and Aksoual (3912 $\mathrm{m}$ a.s.1.), little research has been undertaken to the west of these areas. The area west of Toubkal contains some large high-altitude plateaux that drain into a series of deep valleys. The Tazaghart plateau reaches $3980 \mathrm{~m}$ a.s.l. (above sea level) and combined with neighbouring Adrar Iouzagner (3510 $\mathrm{m}$ a.s.1.) represents the largest area of high ground in North Africa. The area is difficult to access and this probably explains the lack of geomorphological observations from these areas. The only previous observations from this area were made by Dresch (1941) who identified that the valleys surrounding the 
Tazaghart plateau had been glaciated. On the northern cliffs of the Tazaghart plateau a permanent snow patch is marked as 'névé permanent' on topographic maps. This and similar features were also noted by Dresch $(1941$, p. 577) and its significance is discussed in Hughes (2014). In some localities there is debate over the origin of certain landforms. For example, Hughes et al. (2011) argued that former glaciers were larger than Dresch (1941) suggested and some features previously interpreted as rock glaciers have been reinterpreted as rock avalanche deposits (Hughes et al., 2014). Furthermore, separating glacial deposits from torrential fluvial deposits also requires care in this region, an issue noted by De Martonne (1924, p. 302). Sedimentological analyses are therefore required in order to test interpretations of landform genesis, especially for older degraded landforms where only trace remnants survive.

This paper aims to 1) map the evidence for glaciation in the Azzaden valley, north of the Tazaghart plateau and also the area NW of the Tazaghart plateau and Adrar Iouzagner; 2) establish the relative sequence of glaciation using morpholithostratigraphy and quantify the degree of soil weathering on moraine surfaces; and 3) reconstruct different phases of glaciers and also determine the style of glaciation based on the geomorphological evidence and glaciological theory. This information will provide new insights into the Pleistocene history of one of the remotest areas of high terrain in North Africa and contributes new information for understanding the climate of this region, which is strategically positioned between the North Atlantic Ocean and the Sahara, during cold-stage glaciations.

\section{Study Area}

Tazaghart (3980 m a.s.1.) and Adrar Iouzagner (3502 m a.s.1.) are high plateaux situated c. 5$10 \mathrm{~km}$ west of Toubkal (4167 m a.s.1.), the highest mountain in North Africa (Figure 1.). The Tazaghart plateau is one of the largest areas of high land in Morocco with an area of over 2 $\mathrm{km}^{2}$ over $3800 \mathrm{~m}$. Valleys radiate out from this plateau to the north, west and south. The northern edge of the plateau is bounded by steep cliffs ( $>800 \mathrm{~m}$ high). Adrar Iouzagner represents the SW extension of the Tazgahart plateau. This broad ridge extends for $c .3 \mathrm{~km}$ above $3400 \mathrm{~m}$ altitude.

The Tazaghart plateau is largely formed in Precambrian basement volcanics, including basalts, andesites, rhyolites and a range of other intermediate grades (Alaoui Mdaghri et al., 1996; Saadi et al., 1978). The northwestern slopes of Adrar Iouzagner are formed in Precambrian limestone and dolomite, which are exposed along a $10 \mathrm{~km}$ long and $2 \mathrm{~km}$ wide band along this flank with the mountain summits formed in Precambrian andesites. The lower slopes are formed in Cambrian schists. Precambrian granites and other intrusive volcanics are also present locally (in sills and dykes) in the valleys to the north and west of Adrar Iouzagner (such as near Tizgui - see Figure 11). The area experiences a strongly seasonal climate with very hot and dry summers and cool, wet winters. The temperature data for Marrakesh is presented in Table 1 including an estimation of temperatures at 2000 and 4000 $\mathrm{m}$ a.s.l. in the study area. Mean annual temperature at Marrakech is $19.6^{\circ} \mathrm{C}$, with an annual range of $16.1^{\circ} \mathrm{C}$. Annual precipitation is just $281 \mathrm{~mm}$, with most of this falling in winter. In the mountains precipitation is likely to be much greater. Few reliable records exist, but in the Mizane valley draining the north side of Toubkal mean annual precipitation for the period $1949 / 50$ to $1963 / 64$ was measured at $837.3 \mathrm{~mm}$ at $3200 \mathrm{~m}$ a.s.1. and $514.6 \mathrm{~mm}$ at $1900 \mathrm{~m}$ a.s.l. (Messerli 1967, p. 183). 


\section{Methods}

\section{Geomorphology}

The most detailed base map covering the field area is the 1:50,000 topographic map published by Orientazion (2006). This GPS-compatible map (Projection UTM HUSO 29 Datum WGS84) was enlarged and used for field mapping with a handheld Garmin Global Positioning System (GPS). Glacial features were mapped in the field mid-September 2012 and late-April 2013. Field mapping was aided by high resolution satellite imagery $(50 \mathrm{~cm}$ resolution from the GeoEye-1 satellite).

Interpretations of sediment landforms were supported by sedimentological analyses. A lack of section exposures meant that a majority of clast analyses were undertaken on the surface, such as at the crest of sediment accumulations. 50 clasts were taken at random for clasts analysis. Clast shape (a, b, c axes) was measured using calipers and clast roundness estimated using a roundness chart (very angular to well rounded). The $\mathrm{C}_{40}$ and RA indices are used to characterise clast shape. The $\mathrm{C}_{40}$ index is the percentage of clasts with c:a ratios of $\leq 0.4$. Clast populations within subglacial till tend to have a low $\mathrm{C}_{40}$ index and tend to be blockshaped, whilst clast populations within scree tend to have a high $\mathrm{C}_{40}$ index and have a more slab or elongate shape. This is due to the different transport history of clasts within these deposits (Hughes 2004). The RA index is the percentage of angular and very angular clasts in a sample (Benn and Ballantyne 1994). The presence or absence of striae on clast surfaces was also noted. Control samples from deposits of known origin within the study area were used to ensure objective sample interpretation (Benn 2004; 2007). For palaeoglaciology, scree is often used to represent passively transported debris and, thus, 50 clasts from a scree slope in the Azzaden valley were also analysed for clast shape, roundness and presence/absence of striae.

Morphometric analysis was used to assess the cross profiles of valleys. This involved simply drawing slope profiles based on altitude data taken at regular intervals through a cross profile on topographic maps. This was performed to test whether valleys exhibited classic V-shaped or U-shaped morphometries, which are consistent with fluvial or glacial erosion, respectively (Harbor, 1992; Evans, 2008). For more details see Hannah (2014, p. 76).

\section{Soil weathering}

Once landform interpretations were made, based on morphological and lithological criteria, geomorphological surfaces were subdivided on the basis of morphostratigraphy (e.g. Hughes 2010). Surface soils are important in this regard since the degree of soil development can be used to identify and separate surfaces that are widely separated in time. This approach has been successfully employed in a range of contexts in the Mediterranean region to develop a relative-age framework for Pleistocene and Holocene landforms (e.g. Woodward et al. 1994). Soil weathering was quantified using the Harden soil profile development index (Harden 1982). Soil pits were dug up to $120 \mathrm{~cm}$ into landform surfaces. In the field soil profiles were described in accordance with methods described in Harden (1982) and Birkeland (1999, Appendix 1). 
In addition to field observations,samples taken at regular intervals down the soil profiles every $100 \mathrm{~mm}$, c. $200 \mathrm{~g}$ air dried weight, were also analysed in the laboratory following standard procedures for soils (e.g. Woodward et al. 1994; Hannah 2014). Organic content was measured using loss-on-ignition(Dean 1974; Bengtsson and Enell 1986). Particle size was undertaken on the $<2 \mathrm{~mm}$ fraction using a Malvern Instruments Mastersizer 2000. Magnetic susceptibility was assessed using a Bartington Instruments MS2 meter on which low frequency magnetic susceptibility measurements were carried out on a mass specific basis and averaged over three measurement cycles.

\section{Glacier reconstructions}

Different moraine units, subdivided on the basis of morphostratigraphy and soil weathering, provided the basis for glacier reconstructions. Down-valley glacier limits were constrained by moraine crests. Glacier surface profiles were then reconstructed using the Benn and Hulton (2010) model. This model iterates up longitudinal valley-floor profiles and the ice surface profiles are generated from four inputs: long profiles of the bed, shape factors to incorporate the effects of valley-side drag (Nye 1952), target elevations as a guide for the modelled glacier profile, and the yield stress at each step length. Geomorphological evidence constrained target elevations. For example where glacier erosional evidence yields to periglacial landforms such as frost shattered bedrock then this trimline determines the target elevation. Sometimes the target elavtion is defined by the upper edge of a bounding valley side. Where the target elevation can be constrained the yield stress is adjusted until the ice thickness and these empirical measurements correspond. Yield stresses are expected to be in the range 50-150 $\mathrm{kPa}$. Where such evidence was unavailable the standard value of $100 \mathrm{kPa}$ for mountain glaciers was used (Schilling and Hollin 1981; Rea and Evans 2007; Vieira 2008).

Equilibrium line altitudes (ELA) were reconstructed using the balance ratio approach combined with a range of accumulation area ratios. For palaeoglaciers, such as those in Morocco, there are no analogues that can be easily justified and so a global area-altitude balance ratio (AABR) of 1.75 was used (e.g. Rea 2009; Pellitero et al., 2015). A range of accumulation area ratios (AAR) were also applied. For modern mid- and high latitude glaciers, steady state AARs generally lie in the range 0.5-0.8 (Meier and Post 1962, Hawkins 1985), with typical values lying in the range $0.6 \pm 0.05$ (Porter 1975). For a larger global dataset of 144 glaciers, Braithwaite and Raper (2007) found a strong correlation between median glacier elevation (AAR = 0.5) and the average ELA. A later paper by Braithwaite and Raper (2009) presented a strong regression relationship $\left(\mathrm{R}^{2}=0.99\right)$ between median glacier elevation $(\mathrm{AAR}=$ 0.5 ) and the balanced-budget ELA for a global dataset of 94 glaciers with $>4$ years of mass balance records.

Glaciers with debris-covered ablation areas will have lower AARs than clean glaciers because of the effect of thick debris on lowering ablation, increasing the size of the ablation area required to balance accumulation (Müller 1980, Clark et al. 1994). In these circumstances, AAR values may be between 0.1 and 0.5 (Benn and Evans 1998). The occurrence of debris cover is a potential issue for the Moroccan glaciers since large rock avalanches are known to have occurred in glaciated valleys in the area (Hughes et al., 2014). One way to test patterns in glacier hypsometry across a population of glaciers is to plot standard deviation of glacier altitude against the associated accumulation area ratios. The altitude of the snout area within a group of glaciers is likely to vary considerably depending on the hypsometry of the former glaciers. This is why moraine altitude is a poor comparative measure of glacier altitude. Glacier source areas usually show less variability in altitude and will be a function of the average altitude of the mountain 
watershed - which is often controlled by tectonic and structural geology. The lowest variability in altitude in a population of glaciers often occurs somewhere between the snouts and the source areas, i.e. at an AAR somewhere between 1 and 0 . As a result, groups of glaciers will tend to produce an asymmetrical U-shaped curve when standard deviation of altitude against the AARs, with the AAR associated with the lowest standard deviation of altitude corresponding to the average ELA position within a sample of glaciers (Osmaston 2002; Hughes 2004). This approach can also test for other patterns of glacier hypsometry across palaeoglacier populations. For example, where there is an inverse relationship between standard deviation of altitude and AARs then this means that glacier altitudes become more variable in the ablation areas. This may indicate differing levels of debris cover in a population of glaciers.

A simple degree-day model was used to predict the melting at the reconstructed ELAs following the approach outlined in Hughes (2010). Modern mean annual temperatures at Marrakech were extrapolated to the palaeo ELAs for the different glacier phases using a standard lapse rate of $0.6^{\circ} \mathrm{C} / 100 \mathrm{~m}$. Mean annual temperatures were then distributed over a sine curve assuming the same annual range as at Marrakech today. The melt rates are calcuated using a degree-day factor of $4.1 \mathrm{~mm}^{\circ} \mathrm{C}^{-1}$ day $^{-1}$ (Braithwaite 2008). Mean annual temperatures were depressed at a series of $1{ }^{\circ} \mathrm{C}$ steps (from todays temperatures to $12^{\circ} \mathrm{C}$ cooler) and the associated melting was modelled.

\section{Results}

\section{Geomorphology and stratigraphy}

\section{Northern Valleys (Azzaden, Boudareine, Timellite)}

The Azzaden valley drains northwards from the Tazaghart Plateau and has two main tributaries Boudareine and Timellite (Figure 1.). The $>800 \mathrm{~m}$ high northern cliffs of the Tazaghart are some of the largest in the High Atlas. The cliffs hold large volumes of snow in winter and in some gullies the snow lasts all year (see below). The Azzaden valley has a broad floor with a U-shaped or parabolic cross-section in its mid-valley position. The Timellite valley has a similar U-shaped cross-profile (Figure 2.).

The results of clasts analysis at a scree slope in this valley are shown in Figure 3. The clasts have high $\mathrm{C}_{40}$ and RA index values and no surface striae. The clasts of this scree slope were formed of mixed lithologies, basalts, andesites and rhyolites, which is consistent with a majority of the rocks in the study area. This site acts as a control site to which other sites can be compared.

A succession of sediment ridges, mounds and boulder accumulations occur in the Azzaden valley and its tributaries the Boudareine and Timellite valleys. The descriptions and interpretations of these features are outlined below in morphostratigraphical order, from Unit 1 (lowest valley positions) to Unit 4 (highest valley positions).

\section{Unit 1 (Azzaden, Boudareine, Timellite)}

Description: 
The lower boundary of boulder-covered ground marks the boundary of Unit 1 in the Azzaden valley. The boulder-covered ground extends for $c .0 .75 \mathrm{~km}$ from a lower altitude of $2000 \mathrm{~m}$ a.s.l. The boulders vary in lithology and include basalts, andesites and rhyolites. The surface clasts vary in size although the largest are huge with an a-axis of c. $25 \mathrm{~m}$. Sections through the boulder deposits reveal a poorly-sorted matrix-supported bouldery diamiction. Boulders are present up to $200 \mathrm{~m}$ above the modern river channel, which is deeply incised. Clasts analysis was undertaken at two sites, $75 \mathrm{~m}$ above the modern river channel (S1 and S2). The results are presented in Figure 4 and show that clasts at both sites have similar properties. The clasts are largely block-shaped $\left(\mathrm{C}_{40}=24 \%\right.$ and $\left.26 \%\right)$ subangular and subrounded with few angular and very angular clasts (RA index $=20 \%$ and $14 \%$ ). Many of the clasts had striae on their surfaces (48\% and 38\%).

Immediately up-valley, at $c .2200 \mathrm{~m}$ a.s.l. at the confluence of the Azzaden and Timellite valleys, the lower spread of boulders merges into a prominent boulder debris ridge (Figure 5) which splits into two and forms a Y-shaped planform (Figure 1). Clast-form analysis was undertaken at four sites (S3, 4, 5 and 6). Samples S3 and S5 were taken from the crest of the boulder ridge and displayed a mixed assemblage of clast morphologies with a $\mathrm{C}_{40}$ values of $58 \%$ and $64 \%$, respectively. The clasts at these sites were also predominantly angular with RA ratios of $78 \%$ and $64 \%$. No clasts were striated in S3 and only 6\% in S5. Sites S4 and S6, were taken at a mid-point between the crest of the boulder ridge and the valley floor. These samples were more block-shaped $\left(\mathrm{C}_{40}=24 \%\right.$ and $\left.30 \%\right)$, rounder $(\mathrm{RA}=20 \%$ and $16 \%)$ and over a third were striated (36\% and $42 \%)$.

Soil analysis was undertaken in pits dug through the crest of the $\mathrm{Y}$-shaped debris ridge described above. Two soil profiles ( $>1 \mathrm{~m}$ in depth) were analysed (P1 and $\mathrm{P} 2)$ and the results are presented in Table 2. The soil profiles yielded profile development index (PDI) values of 24.0 and 26.3. Additional laboratory analysis was undertaken on P1 (clay content, organic content, magnetic susceptibility) and the results are shown in Figure 6.

The Azzaden valley is fed from the east by the Timellite valley. As with the Azzaden valley, this has a broad floor with a U-shaped or parabolic cross-section in its mid-valley position. The lower part of this valley contains numerous large boulders ( $>5 \mathrm{~m}$ a-axis) that have similar characteristics to the lowest boulder accumulations described in the Azzaden valley above. These boulder deposits also exist in the western tributary of the Azzaden, which is known as the Bouidarene valley. In the areas where the Azzaden and Bouidarene bifurcate there are large areas of exposed smoothed and streamlined basalt bedrock with evidence of striae. This bedrock is steeper than the lower part of the valley and forms a distinct break in slope.

Interpretation:

The lowermost boulder accumulations in the Azzaden valley are interpreted as glacial in origin. The fact that there are no clear moraine ridges suggests that this is an eroded remanent of moraines that extended nearly $0.75 \mathrm{~km}$ from 2000 to $2100 \mathrm{~m}$ a.s.l. The clast characteristics are consistent with active transport with subglacial abrasion resulting in block-shaped clasts that are subangular and subrounded and with many displaying striae. The mixed volcanic lithologies are also consistent with erosion and transport from various points in the valley which is formed in a suite of lavas from basalts to rhyolites. The clasts differ significantly from the control scree sample, allowing an origin via passive slope processes to be discounted. The boulder deposits are also poorly-sorted with boulders situated up to $200 \mathrm{~m}$ 
above the modern river channel. The boulder accumulation also forms a discrete unit of sediment that cannot be traced down-valley beyond an altitude of $2000 \mathrm{~m}$ a.s.1. Thus, a fluvial origin can be rejected. The U-shaped profiles of the upper areas of both the Azzaden and Timellite valleys also supports a glacial origin for the valleys (Fig. 2).

The higher Y-shaped boulder ridge is also considered to be of glacial origin. However, its clast characteristics indicate a mixed transport history. The clasts on the crest of this feature suggest passive transport via supra- or englacial routes, whilst the clasts deeper within the ridge indicate active transport via a subglacial route. A confluence of flow within glaciers draining the Azzaden and Timellite valleys can explain both the surface morphology and clast characteristics of this feature. The merging of two lateral moraines from these valleys has formed a Y-shape sediment ridge in the centre of the valley. This feature is consistent with a medial moraine (Eyles and Rogerson,1978). The surface crests of these medial and lateral moraines are often dominated by passively transported rockfall material (Eyles and Rogerson, 1978; Spedding and Evans 2002). This is supported by the high $\mathrm{C}_{40}$ and RA index values from clasts sampled on the ridge crest. The samples from the crest within the sediment ridge contain clast shapes that are indicative of active transport $\left(\mathrm{C}_{40}\right.$ and $\mathrm{RA}$ index values and evidence of surface striae). This arises from the divergence of flow lines from the glacier bed resulting from lateral compression at the point of glacier confluence (Boulton 1978; Gomez and Small 1985). The presence of both passively and actively transported clasts within this medial moraine may imply that the feature extended from the glacier's surface to its bed (Hambrey et al. 1999) or alternatively, supraglacial medial moraine boulders may have been superimposed on subglacial till during deglaciation (e.g. Schomacker 2011).

The soils on the surface of the medial moraine are thick and well-developed. This is indicated by PDIs of 24.0 and 26.3. The additional laboratory results from P1 (Figure 6) show that this soil has greater magnetic susceptibility, organic and clay content than soils on higher strtigraphical units, which is an indication of greater weathering.

In the upper Azzaden and Bouidarene valleys, extensive areas of smoothed, streamlined and striated bedrock surfaces are mapped as ice-moulded bedrock. The break in slope formed by this bedrock is characteristic of a glacial rock-step with greater basal shear stresses enhancing erosion. The rock-step itself appears to be caused by a band of resistant fine-grained basalt.

All the landforms described in this section are grouped as part of a single glacial stratigraphical unit, Unit 1 . They represent the oldest and most extensive glaciation in the area, here termed the Phase I glaciation.

\section{Unit 2 (Azzaden, Timellite)}

\section{Description:}

In the Azzaden valley between 2605 and 2840 is a second pronounced boulder ridge, this time with a single crest measuring $560 \mathrm{~m}$ in length. It is positioned up-valley of the striated basalt bedrock step described in Unit 1 (Figure 1 and 7. Photo). The ridge extends laterally parallel to the valley but is slightly arcuate in its lower portion. Sedimentological analysis at two locations on the ridge crest (S7 and S8) shows that clasts had low $\mathrm{C}_{40}$ index values $(26 \%$ and 38\%), low RA values (18\% and 30\%) indicating most clasts were block-shaped with a dominance of subangular and subrounded clasts. Some clasts were also striated $(36 \%$ and $20 \%)$. 
The equivalent morphostratigraphical unit in the Timellite valley begins at $2920 \mathrm{~m}$ a.s.1. where a boulder ridge crosses the eastern side of the valley. Clast analysis (S13) indicated low $\mathrm{C}_{40}$ and RA indices ( $28 \%$ and $8 \%$ respectively) and $46 \%$ of clasts were striated. In the Bouidarene valley there are no clear boulder accumulations that correlate with Unit 2 of the Azzaden and the Timellite valleys.

Two soil profiles ( 80 and $75 \mathrm{~cm}$ thick) were analysed on the large boulder ridge in the Azzaden valley (P3 and P4) and the results are presented in Table 2. The soil profiles yielded profile development index (PDI) values of 14.3 and 11.5. Additional laboratory analysis was undertaken on P3 (clay content, organic content, magnetic susceptibility) and the results are shown in Figure 6.

Interpretation:

The large boulder ridge in the Azzaden valley is interpreted as a lateral moraine that was formed by a large valley glacier emanating from the northern cirque of the Tazaghart (3980 $\mathrm{m}$ a.s.1.) and the western cirques of Biguinnoussene (4002 m a.s.1.) and Afella North (4040 m a.s.1.). This glacier appears to have stabilised above a basalt rock step. The equivalent transverse ridge in the Timellite valley is interpreted as a terminal moraine of a glacier emanating from the northern cirque of Biguinnoussene.

The soil profile data shows that the soils on this moraine are less weathered that the moraines of Unit 1. The PDIs are lower and the soil profiles contain less organic and clay content and also display lesser magnetic susceptibility in the lower half of the profile compared with Unit 1 moraine soils (Fig. 6). This supports the separation of these moraines as two morphological units as they appear to be significantly separated in time and not simply recessional or standstill moraines associated with the same glacial phase.

\section{Unit 3 (Azzaden, Timellite)}

\section{Description:}

A third boulder ridge is present at 3050-3100 $\mathrm{m}$ a.s.1. below the northern cliffs of Tazaghart (Figure 1 and 8). It is a single landform with two arcuate parallel crests, $10 \mathrm{~m}$ apart. The southern ridge crest is the largest and has a length of $220 \mathrm{~m}$ and amplitude of $35 \mathrm{~m}$ above the valley floor. Clast analysis from two sites (S9 and S10), one on each crest, show similar results. Both samples have low index values for $\mathrm{C}_{40}(28 \%$ and $26 \%)$ and $\mathrm{RA}(28 \%$ and $29 \%)$ and contain numerous striated clasts (50\% and $32 \%$, respectively).

Two soil profiles were dug in the crests of the sediment ridges (P5 and P6). These revealed thin soils (30 and $40 \mathrm{~cm}$ ) that yielded PDI values of 2.3 and 3.0. The soils have lower organic and clay content and also lower magnetic susceptibility than the soils on the lower morphological units (Fig. 6).

The 900 m-high north-facing cliffs of Tazaghart are directly to the south of the boulder ridge. To the SE, in the upper valley area between Tazaghart and Afella a collection of $>50$ boulders are present, of varying lithology, largely subrounded or subangular and with some displaying evidence of striae. The col (Tizi Melloul) between Tazaghart and Afella has an elevation of c. $3850 \mathrm{~m}, 100-200 \mathrm{~m}$ below the peaks either side. Large ( $>1 \mathrm{~m}$ diameter) 
perched and subangular boulders are present close to the col. The col is relatively broad and does not form steep cirque headwalls on either side. However, steep cliffs are situated on either sides of the col especially the northwest and southwest faces of Afella and the southeastern slopes of Tazaghart. Steep cliffs are also visible in satellite images at the heads of several other valleys draining south from Tazaghart, although this area was not visited.

A third boulder ridge is also present in the Timellite valley at c. $3350-3400 \mathrm{~m}$ a.s.l. on the western side of the valley. Clast analysis (S14) indicated low $\mathrm{C}_{40}$ and RA indices (32 and $20 \%$ respectively) and $34 \%$ of clasts were striated.

\section{Interpretation:}

The boulder ridges are clearly moraines similar to those identified lower in the valleys. The Azzaden moraine was formed by a cirque glacier that was banked up against the northern face of Tazaghart. The arcuate moraines crests are approximately parallel to the cliffs and today this cliff supports permanent snow fields (see below and Figure 8). The Timellite moraine was formed by a cirque glacier that nestled in the north-facing cirque of Biguinnoussene. This is one of the clearest and best-developed cirques of the High Atlas.

The soil PDIs are much lower than for the Unit 2 moraines further down-valley. The fact that the soils were thin and had lower organic and clay content and also lower magnetic susceptibility than the soils on the lower moraines (Fig. 6) is consistent with a younger age.

There is no morphological evidence to support that ice came from the western cirque of Biguinnoussene (4002 $\mathrm{m}$ a.s.1.) and Afella North (4040 m a.s.1.). It is clear that this high cirque area has been glaciated but no deposits equivalent to the Unit 3 moraines below the Tazaghart cliffs were found. However, the numerous glacial boulders in this area indicate glacier transport. The geomorphology of the Tizi Melloul area between Tazaghart and Afella suggests that the col has been breached by erosive ice draining both to the north and to the south. The ice eroded and moulded bedrock over the col, which is particularly evident on the western side on the slopes leading up to Tazaghart. The ice transported and deposited glacial boulders which are now perched near the col and also formed cirque headwalls on both the southeastern slope of Tazaghart and the western faces of Afella either side of this col. The direction of ice movement could have been from the north or the south or diffluent from the col area (in Fig 1 the arrows depicting ice moulding are simply illustrative of this and not necessarily indicating ice flow direction). This area is assumed to have last been glaciated in association with the valley glacier that formed the Unit 2 moraines (see above) with glaciation also occuring during the most extensive glacial phase associated with the Unit 1 moraines. The area south of this col was not studied but it is clear from satellite images that the southern flanks of Tazaghart are glaciated with ajoining cirque walls south of the highest summit (3980 m a.s.1.) forming an arête spur (Fig. 2).

\section{Unit 4 (Azzaden)}

\section{Description:}

A fourth boulder unit is present bounding a snow patch close to the northern cliffs of Tazaghart between 3320 and $3440 \mathrm{~m}$ a.s.l. (Figure 9). This snow patch was present in late September 2012 (Figure 10) and covered an area of $2345 \mathrm{~m}^{2}$. The feature is marked on several topographic maps (including the US Army Map Service 1943, compiled from the 
Service Géographique du Maroc 1937 to 1940; and also a 1994 edition from the latter) and has been noted by several authors including Dresch (1941, p. 577), Smith (2004, p. 84), Hannah (2014) and Hughes (2014). It is positioned within and directly in front of one of the largest gullies cut into the cliff face. Two prominent sediment ridges flank and extend beyond this snow patch (Figure 10). The ridges are linear in planform and measure $168 \mathrm{~m}$ (west ridge), and $167 \mathrm{~m}$ (east ridge) in length and are $62 \mathrm{~m}$ apart at their widest point. The two sediment ridges are clast-supported with the largest being boulder-sized with an average aaxis of c. $1 \mathrm{~m}$ and the largest boulders having an a-axis $>5 \mathrm{~m}$. Clast analysis on each ridge (S11 and S12) indicate mid RA (48\% and 40\%) and $\mathrm{C}_{40}(42 \%$ and $38 \%)$ values and a low percentage of striated clasts $(16 \%$ and $20 \%)$ (Figure 9$)$. Whilst the ridge sediments are predominantly clast-supported boulders there is a significant quantity of a finer matrix grading from cobbles to fine silts (very poorly sorted) and the sediment is a clear diamicton.

Two pits were dug on either crest. No soil development was apparent and thus these surfaces were assigned a PDI value of zero. Laboratory analysis shows that the material contains negligible organic material $(<0.65 \%)$ and confirms its interpretation as parent material with no soil development (Table 2).

Interpretation:

The position of the sediment ridge, bounding the lower area of a large couloir (gully) that today contains perennial snow combined with the sedimentological characteristics of the landform suggests it is a moraine ridge. The key sedimentological indicators are the presence of striated clasts and the very poorly-sorted nature of the sediments with a significant presence of fines. The presence of striae and fine-grained matrix is important because this is consistent with subglacial abrasion and clast crushing under a dynamic ice mass. The presence of fines in addition to coarser clasts is also consistent with glacial sediments and inconsistent with fluvial sediments which would be well-sorted. Whilst overall the clasts are more angular and less block-shaped compared with lower moraine units, this is to be expected given the small transport distances from the cliff face to the ridges.

Combined with the gully above the bounding ridges, snow and ice could potentially cover an area of 1.49 hectares $\left(0.0149 \mathrm{~km}^{2}\right)$, which is 6 times larger than the snow patch observed in September 2012. Dynamic ice bodies have been observed covering just 1-5 hectares (0.01$0.05 \mathrm{~km}^{2}$ ) in other marginal settings in other Mediterranean mountains (e.g. Grunewald and Scheithauer 2010; Hughes 2009, 2010). Furthermore, the sediments ridges are not parallel to the cliff face, unlike what would be expected in the case of a snow patch and associated pronival or protalus rampart. The distance from the outermost parts of the bounding ridges to the break of slope at the cliff face is over $150 \mathrm{~m}$. Modelling of threshold conditions for the formation of dynamic ice or firn indicates that the maximum distance between a protalus rampart and the talus foot upslope cannot exceed 30-70 m (Ballantyne and Benn 1994). This criterion may be complicated by the fact the morphology of the bounding lateral sediment ridges at this site would enable any snow patch to have a lesser gradient than if it was bounded by a sediment ridge parallel to the cliff face, thus extending this threshold distance.

The ridges and intervening channel could also be interpreted as an incised alluvial fan or debris cone at the base of a gully, which is a common morphology in many parts of the High Atlas (Dresch 1941). In the case of snow-filled gullies such a feature could also be described as a nival fan (e.g. Christiansen, 1998). However, based on the the overall geomorphology and sedimentological characteristics, these features are interpreted as moraines formed by the 
last glacier in the Azzaden valley. The lack of any soil development suggests a recent age for the moraine. This is consistent with the hypothesis that this moraine was formed by a small dynamic ice mass during the Little Ice Age (Hughes 2014). It is possible that dynamic ice existed until the late 20th Century given that 'névé permanent' is marked on topographic maps dating to the 1940s (US Army Map Service 1943). There are no lichens on the boulders of this moraine, although a thorough lichenometrical assessment of other surfaces in the area has not been carried out. Anecdotal evidence from local guides suggest that this snowpatch is no longer truly permanent since it is reported to have disappeared completely in some recent years.

\section{Western Valleys (Tougdal, Tizgui, Amizmiz, Oussal, Ameslane)}

The western area of the Tazaghart and Iouzagner consists of five valleys: Tougdal, Tizgui, Amizmiz, Oussal, and Ameslane (Fig. 11). These were all approached from the village of Tisgui which can be reached by a dirt track $10 \mathrm{~km}$ east of the main Tizi n'Test road (R203) in the Nfis valley.

\section{Unit 1 (Tougdal, Tizgui, Amizmiz, Oussal, Ameslane)}

\section{Description:}

The five valleys draining the western slopes of Tazaghart and Iouzagner all contain ridges and mounds of bouldery diamicton deposits (Figure 11), all at a similar elevation between 2000 and $2100 \mathrm{~m}$ a.s.1. and formed of a variety of basalts, andesites and rhyolite (Figures 12 and 13). Clast analysis was undertaken on these deposits in each of the five valleys. The results are summarised in Table 3 . The $\mathrm{C}_{40}$ ratios vary from 24 to $42 \%$ and the RA ratios from 18 to $32 \%$. These results show that less than half of clasts were slab- or rod-shaped (a majority being block-shaped) and less than a third of clasts were angular or very angular (a majority being subangular and subrounded). These results show that the diamicton boulders have similar characteristics to those in the Azzaden and Timellite valleys. In all valleys at least some of the boulder clasts were striated, with the frequency of striated clasts varying from 16 to $54 \%$.

Whilst the summits are formed on the usual igneous rocks, a $2 \mathrm{~km}$ wide band of Precambrian limestone crosses the middle parts of the Tizgui, Amizmiz, Oussal, Ameslane valleys. The lower valley slopes are formed in a Precambrian calcareous schist (Service Géologique du Maroc 1996). These calcareous lithologies form shattered bedrock features in these valleys at an altitude of c. $2200 \mathrm{~m}$ a.s.1. (Fig. 13) and some rise up to c. $100 \mathrm{~m}$ above the valley floor and resemble tors. Large subangular and subrounded basalt, andesite and rhyolite boulders are present resting on the calcareous bedrock and form linear accumulations perched on the lateral margins of the valleys (Figures 12 and 13).

Soils were not analysed in the western valleys because the remoteness and scale of the sites limited the time available for the digging of pits and soil-profile observation.

Interpretation:

The boulder ridges and mounds are interpreted as moraines formed by glaciers emanating from Tazaghart and Iouzagner. The clast shape and roundness and presence of striated clasts supports this interpretation. The concentration of these deposits between 2000 and $2100 \mathrm{~m}$ 
a.s.1. in all the valleys is consistent with the presence of an ice front at $2000 \mathrm{~m}$ in the Azzaden valley. The mixed volcanic boulder lithologies are erratics resting on calcareous bedrock below the tors and this indicates transport of bedrock material eroded from the upper catchments. Only one of the valleys, Tougdal, has a clear cirque backwall (Figure 1) although large parts of this valley drain directly from the Iouzagner and Tazaghart plateaux with no evidence of cirque incision. This suggests that the five valley glaciers west of Iouzagner and Tazaghart drained a plateau ice field or ice cap (see below in glacier reconstructions).

\section{Units 2 and 3 (Tougdal)}

\section{Description:}

Two sets of boulder ridges are present in the upper Tougdal valley. The lower of these is situated at an altitude of c. 2500-2700 m a.s.l. Clast analysis (S17) shows that surface boulders were predominantly block-shaped $\left(\mathrm{C}_{40}=30\right)$ and subrounded/subangular $(\mathrm{RA}=$ $18 \%$ ) with striae present of $24 \%$ of clasts. The higher boulder ridge is present between 2650 and $2800 \mathrm{~m}$ a.s.l. Clast analysis (S18) shows that surface boulders were predominantly blockshaped $\left(\mathrm{C}_{40}=30\right)$ and subrounded/subangular $(\mathrm{RA}=20 \%)$ with striae present on $36 \%$ of clasts.

To the north of these boulder ridges the bedrock of the ridge above the Tizi Tougdal col is shattered. To the northeast of the boulder ridges, the valley is enclosed by steep cliffs.

Interpretation:

These deposits are comparable with those in the lower valley that are interpretetd as moraines. The position of these deposits is similar to the moraines of Unit 2 in the Azzaden and Timellite valleys. The highest deposits of Unit 3 in the Tougdal valley are at a lower altitude (by 200-400 m) than the Unit 3 moraines in the Azzaden and Timellite valleys. It is possible therefore that Units 2 and 3 in the Tougdal valley correlate with Unit 2 in the Azzaden and Timellite valleys. However, the size of the Units 2 and 3 moraines indicate significant standstills or advances. No equivalent recessional moraines were observed in the Azzaden and Timellite valleys and the two moraines in the Tougdal valley are considered as separate stratigraphical units. No soil data were collected from the Tougdal valley to test this hypothesis further. The bedrock above the Tizi Tougdal col does not display any evidence of ice moulding nor contains any erratics, but instead appears to be frost-shattered. This provides some constraints on ice limits in this area. The cliffs that bound the NE edge of the valley provided the headwall for a glacier that formed the moraines of Units 2 and 3.

\section{High level deposits and landforms}

\section{Description:}

Erratic boulders are present in the higher parts of the Tougdal valley between 2900 and 3300 $\mathrm{m}$ a.s.l. At least five large ( $>5 \mathrm{~m}$ diameter) boulders were identified and these are marked on Figure 11. All of these were subrounded or subangular and striated. The boulders we composed of the local basalts, andesites and rhyolites but were clearly different in composition to the immediate underlying rock (the volcanic rocks vary locally between these grades of extrusives) and, thus, the boulders are technically erratics and have clearly been moved to their current positions. 
Large areas of the Tazaghart and Iouzagner plateaux are covered by broken regolith (angular gravel-, pebble- and cobble-sized rock fragments and depth up to several metres). Areas between 3000-3600 $\mathrm{m}$ a.s.1. are characterised by pronounced patterned ground that is visible from on satellite images. The patterns are polygonal in the higher part of this zone, which has a gentler gradient at slope convexities leading to the higher plateaux. The patterns become linear on steeper slopes down theis convex slope profile. These linear features are $\sim 10-20 \mathrm{~m}$ wide and up to $1000 \mathrm{~m}$ long and clearly visible on satellite images, especially around Iouzagner. On the ground the stripes have variable compositions and consist of both sorted and unsorted clasts ranging in size from sand to cobble.

Interpretation:

The presence of erratic boulders between 2700 and 3300 indicates ice flow and subglacial boulder transport from the plateaux of Tazaghart and Iouzagner into the Tougdal valley. These boulders are not associated with Units 2 and 3 but are related to Unit 1 moraines which were formed by outlet glaciers from a plateau ice-field that covered the Tazaghart and Iouzagner plateaux.

The lack of ice-moulded bedrock and presence of mountain-top regolith and blockfields in the high plateau areas (Figure 1) suggests that the former ice masses were cold-based in their highest parts (Kleman, 1994). However, some of the periglacial features may be post-date glaciation, since Couvreur (1966) and Robinson and Williams (1992) both argued that periglacial processes are still active today above $2000 \mathrm{~m}$ a.s.l. Whilst the highest plateaux may have been covered by cold-based ice, the mid- and lower glacier areas must have been warm-based since glacial valleys have been carved resulting in large morainic accumulations in the lower valley areas. In addition, the drainage divide between Tazaghart and Afella is clearly over-deepened and ice-moulded.

The broken regolith boulder fields of the plateau summits are frost-shattered bedrock features. The patterned ground on convex slope profiles immediately below the frostshattered plateaux are also interpretetd as periglacial features. The linear features on the steeper lower parts of these convex slopes resemble stone stripes. The transition of patterned ground from polygons and circles on gentler slopes to stone stripes on steeper slopes is characteristic of periglacial patterned ground (Büdel 1960). Stone stripes are thought to be controlled by soil texture, ice growth and local slope (Werner and Hallet 1993). The presence of stone stripes within former glacier limits either indicates preservation of such features under cold-based ice or it implies formation after deglaciation (see later discussion on the age of the glaciations).

\section{Other areas}

The extent and geometry of glaciers draining to the southeast of Iouzagner and south of Tazaghart, in the valley containing Azib Ifergane remains unclear as this valley was not visited. However, cirques are present on the south side of the Tazaghart plateau. As with the northern edge of this plateau, these steep cliffs would have constrained the margins of Tazaghart ice field and any glaciers south of this plateau would have emanated from the cirques themselves. The ice-field situated over Iouzagner is not constrained in this way and ice is likely to have flowed southeastwards unimpeded. However, moraines associated with 
the most extensive glaciers and smaller later phases have not yet been identified. Topographic maps and satellite images do reveal an interesting arcuate ridge bounding a shallow basin at Azib Ifergane itself. Whether this is moraine, a rock avalanche deposit or a structural bedrock landform remains unknown and requires further investigation.

Another valley, the Assif n'Ouarhou, between the Tougdal valley and the Boudareine valleys (southwest of Aourirt n'Irg 3210 m a.s.l. in Fig. 1) was not visited. However, this is also likely to have been glaciated. The valley displays superficial morphometry similar to glaciated valleys elsewhere in the area. In Figure 15, areas where glaciers have not been reconstructed, but are likely to have been present, are marked by question marks.

\section{Glacier reconstructions}

\section{Phase I glaciation}

The Phase I glaciers are associated with Unit I moraines. During this largest recorded glaciation plateau ice fields and their outlet glaciers covered an area of $25.09 \mathrm{~km}^{2}$ over the Tazaghart and Iouzagner plateaux (Table 4). The plateau ice fields were drained by large valley glaciers. These reached lengths of up to $5-7 \mathrm{~km}$ in both the northern and western valleys. The longest glaciers were the Azzaden and Tougdal glaciers, which both reached around $7 \mathrm{~km}$ in length (Figure 15). Ice would have also drained southeast from Iouzagner and south from Tazaghart towards the valley containing Azib Ifergane. However, the lower limits of these ice masses was not constrained by field observations and these areas were omitted from the glacier reconstructions.

In the Azzaden Valley the former glaciers had their source in cirques which provide clear constraints on glacier reconstructions in upper areas. On the NW slopes of Iouzagner and Tazaghart the lack of cirques at the head of the glaciated valleys suggests that the glaciers drained an ice surface that covered the high plateaux which characterise these peaks. Both the geomorphology and the modelled glacier profiles produced in the Benn and Hulton (2010) model support this. The ice surface reconstructions are shown in Figure 15. The ice masses over the Iouzagner and Tazaghart plateaux were constrained by topography. This was especially the case over the Tazaghart plateau which is bounded by steep cliff edges, although the modelled ice surface over Iouzagner was also influenced by underlying topography. These characteristics and the fact that ice covered areas of $<100 \mathrm{~km}^{2}$ means that the glaciers that covered Tazaghart and Iouzagner are best described as plateau ice fields (cf. Rea et al., 1999; McDougall 2001; Evans et al., 2002; Rea and Evans 2003) rather than ice caps.

A total of nine glacier segments were identified for the basis of glacier reconstruction for the most extensive glacial phase. These were separated on the basis of ice-drainage divides or ice sheds. Within these, a total of 14 long profiles and 38 typical cross-sections were used for the application of the Benn and Hulton (2010) model. The calculated shape factors for the valleys were fairly consistent throughout, ranging from 0.66 to 0.42 . In the few areas where the ice thickness was constrained, basal shear stress values in the range 70 to $100 \mathrm{kPa}$ produced ice thicknesses and surface profiles that aligned well with the geomorphological evidence. The ice surfaces produced using these stress values closely fitted the shape and amplitude of constraining valleys and also the periglacial evidence (frost shattered outcrops ) of upper ice limits on valley interfluves (Figure 15). Due to the small size of the Tazaghart and Iouzagner 
plateaux, the modelled glacier thicknesses indicate thin ice over these surfaces: $90 \mathrm{~m}$ thick over Iouzagner and $135 \mathrm{~m}$ thick over Tazaghart. Cold temperatures on these plateaux $(>3600$ $\mathrm{m}$ a.s.1.) and relatively thin ice would have favoured cold-based ice in the highest areas and this is consistent with the geomorphological evidence.

When applying a balance ratio of 1.75 the nine glacier segments yielded ELAs ranging from 2609 to $2994 \mathrm{~m}$ a.s.l. (mean $=2829 \mathrm{~m}$ a.s.1.). The standard deviation of altitude for the population of glaciers shows that there was little variation in glacier frontal altitudes compared with source areas which show much greater variability (Figure 16). However, the relationship is not linear, with standard deviations increasing from AAR 1 to AAR 0.6 then reversing to AAR 0.2, then increasing again to AAR 0. On the basis of the standard deviation results no AAR stands out as the most appropriate (Figure 16) and, thus, in these circumstances it can be argued that based on global relationships between the AAR and the ELA, then an AAR of 0.5 should be applied (Braithwaite and Raper 2007, 2009). Given the possibility of debris-covered glacier surfaces, an AAR of 0.5 is the best compromise rather than assuming a higher AAR such as 0.6, which is often adopted for mountain glaciers (e.g. Porter 1975, Hughes 2007). The mean ELA using an AAR of 0.5 ranged from 2650 to $3262 \mathrm{~m}$ a.s.l. (mean $=3002 \mathrm{~m}$ a.s.1.).

\section{Phase II glaciation}

The Phase II glaciers are associated with the Unit II moraines. These were formed by three valley and cirque glaciers, in the Azzaden, Timellite (northern valleys) and Tougdal valleys (western valleys). These glaciers covered areas of $2.09,0.83$ and $0.66 \mathrm{~km}^{2}$, respectively and reached lengths of 1 to $3 \mathrm{~km}$. The largest glacier, the Azzaden glacier, had its source in two areas: below the northern cliffs of Tazaghart and also in the high col between Tazaghart and Afella. The latter source would have formed an ice divide with ice not only draining northwards to the Azzaden valley, but also southwards too towards Azib Ifergane (Figure 15). The Timellite glacier was a simple valley glacier stretching $2 \mathrm{~km}$ northwards from the northern cirque of Biguinnoussine. The Tougdal glacier was west-facing cirque glacier reaching just over $1 \mathrm{~km}$ in length on the western slopes of Tazaghart.

When applying a balance ratio of 1.75 the three glaciers yielded ELAs of $2779 \mathrm{~m}$ (Tougdal), $3305 \mathrm{~m}$ a.s.l. (Azzaden) and $3330 \mathrm{~m}$ (Timellite) (mean $=3138 \mathrm{~m}$ a.s.1.). Given the small sample of glaciers the standard deviation of AAR approach was not applied and instead the ELA associated with the median elevation of the glacier was calculated, for comparison with the Phase I glaciers. Using an AAR of 0.5 (median elevation of the glacier) the ELAs of the Phase II glaciers were 2815, 3420 and $3424 \mathrm{~m}$, respectively (mean $=3220 \mathrm{~m}$ a.s.1.), which represents a variation of +1.3 to $+3.5 \%$ on the ELAs calculated using the global balance ratio.

\section{Phase III glaciation}

The Phase III glaciers are associated with the Unit III moraines. These were formed by three small cirque glaciers; in the same valleys as those associated with the Phase II glaciers. The Phase III glaciers covered areas of $0.38 \mathrm{~km}^{2}$ (Tougdal), $0.82 \mathrm{~km}^{2}$ (Azzaden) and $0.42 \mathrm{~km}^{2}$ (Timellite) and were situated in the high cirques and were less than $1 \mathrm{~km}$ long. Using a balance ratio of 1.75 the ELAs of these glaciers were $2867 \mathrm{~m}$ (Tougdal), $3358 \mathrm{~m}$ (Azzaden), $3475 \mathrm{~m}$ (Timellite) (mean $=3233 \mathrm{~m}$ a.s.1.). Using an AAR of 0.5 (median elevation of the glacier) the ELAs of the Phase III glaciers were 2892, 3471 and $3508 \mathrm{~m}$, respectively (mean 
$=3290 \mathrm{~m}$ ), which represents a variation of +0.9 to $+3.4 \%$ on the ELAs calculated using the global balance ratio.

The presence of at least three phases of glaciation is reserved to just three valleys yet is absent in other valleys where one might expect a similar sequence of glaciation. For example, in the Bouidarene valley Phases II and III are absent. This may be due to preservation issues. The steepness of the Bouidarene valley, which is the steeper than all other glaciated valleys, means that moraines associated with Phase II and III glaciers may have been eroded, or reworked. The absence of Phase II and III moraines in the western valleys of Tazaghart and Iouzagner is more understandable since these valleys were glaciated by plateau ice source which was only present in the largest glacial phase (Phase I).

\section{Phase IV glaciation}

The Phase IV glaciation is represented by the highest moraine unit in the Azzaden valley, at the 'névé permanent'. This glacier would have covered an area of just 1.49 hectares $(0.0149$ $\mathrm{km}^{2}$ ). The ELA of this feature is unlikely to have been fixed year-on-year. In these niche topoclimatic settings glaciers can experience positive mass balance over the whole surface in some years and negative mass balance in others (Hughes 2008, 2009). Avalanche (and windblown) inputs can represent major contributions to mass balance. Rock avalanches can also mean that these features experience intermittent debris cover which again can have a major affect on mass balance. Thus, the concept of an ELA on such small niche glaciers is not comparable with larger glaciers. This glacier is best described by its altitudinal range, which was 3320 to $3440 \mathrm{~m}$ a.s.1.

\section{Climate Reconstructions}

There are no glaciers in the High Atlas today because insufficient snow accumulates to balance melting. At $4000 \mathrm{~m}$ a.s.l. near the highest summits of the area, the annual temperature is $c .-1.5^{\circ} \mathrm{C}$ which produces an annual melt of $2780 \mathrm{~mm}$ using a degree-day model. This melt value is well above the annual precipitation measured in the central Toubkal massif. For the period $1949 / 50$ to $1963 / 64$ precipitation was $837.3 \mathrm{~mm}$ at the Neltner Refuge (3200 $\mathrm{m}$ a.s.1.) (Messerli 1967, p. 183).

Under today's temperatures the annual melt at the ELA $(\mathrm{AAR}=0.5)$ of the Phase I glaciers would be $7822 \mathrm{~mm}$, at Phase II $6540 \mathrm{~mm}$ and at Phase III $6167 \mathrm{~mm}$. In order to produce melt of $<1000 \mathrm{~mm}$ (i.e. balanced by modern measured precipitation values, in the form of snow) then temperatures need to be depressed by $>9^{\circ} \mathrm{C}$ during Phase I glaciation and by c. $7-8^{\circ} \mathrm{C}$ during the Phase II and III glaciations (Table 5).

If precipitation was greater than today then smaller temperature depressions would be required in order to sustain glaciers at the ELAs of the Phase I, II and III glaciers. It is possible that climate was wetter during the Pleistocene cold stages in Morocco, and a more southerly track of depressions has been suggested for the Last Glacial Maximum with the moisture transport coming from the Atlantic across Morocco and then veering northwards to the Alps (Luetscher et al. 2015, their Fig. 1). However, there is very little independent evidence to constrain either Pleistocene cold-stage temperatures or precipitation in Morocco. Nevertheless, these glacier reconstructions illustrate the magnitude of climate changes that are required to form glaciers recorded by Pleistocene moraines in the High Atlas. 
It must be noted that the temperature-melt reconstructions in Table 5 are associated with depressions of mean annual temperature that are associated with the same annual temperature range as today at Marrakech $\left(16.1^{\circ} \mathrm{C}\right)$. It is unlikely that temperature range would have been less than today during cold stages (cf. Isarin et al. 1998) and this means that the melt values in Table 5 are minimum estimates associated with the series of temperature depressions. However, as with precipitation and air temperatures, there are no independent proxies that can help constrain annual temperature range for Morocco and this element of the glacierclimate modelling remains a challenge

The comparison of reconstructed ELAs with modern altitudes is complicated by Quaternary orogenesis. Tectonic uplift is clearly active in the High Atlas and has occurred throughout the Quaternary shaping the mountains we see today (Stokes et al., 2008; 2015; Delcaillau et al. 2010; Babault et al. 2012). Thus, the ELAs given here above modern sea level would not be the same altitudes above Pleistocene sea levels. Lower eustatic sea levels during Pleistocene cold stages offsets this uplift effect, but establishing a reliable palaeo-ELA that takes into account of both eustasy and mountain uplift is problematic, especially given that the latter is not established for the study area. Despite these complications, if uplift is assumed to be uniform over the period represented, then comparisons between the ELAs for the three glacier phases are still valid.

For the single Phase IV glacier temperatures need to be depressed by $6-7^{\circ} \mathrm{C}$ in order for melting to be balanced by accumulation of $1000 \mathrm{~mm}$ - the estimated modern precipitation at this site. However, the glacier is likely to have been present as recently as the Little Ice Age when temperatures depressions were relatively small $\left(\sim 1^{\circ} \mathrm{C}\right)$. This implies that accumulation must have been much greater than $1000 \mathrm{~mm}$ at this site in order to offset high melt rates. Today the annual melt is modelled at $5366 \mathrm{~mm}$ and with a $1{ }^{\circ} \mathrm{C}$ depression it is $4534 \mathrm{~mm}$. Thus, in order to sustain a glacier today or during the Little Ice Age at this site then snow accumulation must have been at least four times the water equivalent value in direct meteorological precipitation. This is only achievable with large avalanche and windblown snow inputs. The historical (and current) observations of perennial snow at this site, and the geomorphological evidence of recent glacier movement, illustrates how local topoclimates can completely decouple glaciers and snow patches from regional climate (e.g. Hughes 2008, 2009).

\section{Age of the glaciations}

The glacial sequence in the Tazaghart and Iouzagner is subdivided based on morphostratigraphy and soil stratigraphy, which each provide a relative measure of chronology. However, no radiometric ages are available and therefore geochronological control is lacking. However, correlations can be made with dated moraine sequences in neighbouring valleys in the Toubkal and Aksoual areas. The detailed data from these valleys has not yet been published but summaries of preliminary cosmogenic exposure ages have been published in Hughes et al. (2011a; 2011b) and Fink et al. (2012; 2014). The lowest and most extensive moraines, correlating with Phase I glaciation in this study, have yielded exposure ages of 30-88 ka. The precise age of these moraines remains unclear but they certainly pre-date the global Last Glacial Maximum (LGM; 27-23 ka, Hughes and Gibbard 2015). A higher set of moraines, correlated with Phase II glaciation in this study, have been dated at 19-25 ka. These equate closely with the LGM. A third moraine unit, correlated with 
Phase III glaciation in this study, has yielded exposure ages of 11 to $13 \mathrm{ka}$. These equate closely with the Younger Dryas Chronozone (12.9-11.7 ka). These moraines therefore all belong to the last glacial cycle, which is known as the Soltanien Stage in Moroccan stratigraphy (Lefèvre and Raynal 2002).

There is no evidence for Middle Pleistocene glaciations unlike in other parts of the Mediterranean (e.g. Giraudi et al. 2011; Hughes et al. 2006; 2010; 2011; Villa et al. 2013). This is either because the Soltanien glaciers were larger than in earlier glaciations or simply because of erosion of older moraines. Unlike in other areas, especially karstic areas where moraines often become cemented and drainage is subterranean (e.g. Adamson et al. 2014; Žebre and Stepišnik, 2015), the preservation potential for moraines in the steep catchments of the High Atlas is poor. Finally, as already discussed, the highest Phase IV glacier is Holocene in age and has been correlated with the Little Ice Age event (Hughes 2014).

The age of the glaciations described above has implications for the history of the periglacial landforms which are present within the most extensive glacial limits. The presence of thick regolith, blockfields and stone stripes within glacier limits of Phase I age can be explained by either preservation under non-erosive cold based ice cover or if periglacial features formed after the most extensive phase of glaciation. None of the pronounced periglacial features marked in Figures 1 and 11 occur within the limits of the later glacier phases. Furthermore, in the western valleys of Tazaghart and Iouzagner the patterned ground occurs in the lower valley areas that would have been occupied by erosive warm-based glaciers. This implies that the patterned ground post-dates the last glaciation of these areas which pre-dates the global LGM (see above).

\section{Significance of the Tazghart and Iouzagner plateau ice fields}

The former plateau ice fields of the Tazaghart and Iouzagner represented some of the largest contiguous ice masses in the Atlas Mountains, and also in North Africa. Further afield in East Africa, over $5000 \mathrm{~km}$ to the SE, large glaciers are known to have formed over the Ethiopian Highlands, Mount Kenya, Kilimanjaro and the Ruwenzori during the Pleistocene (Osmaston and Harrison, 2005; Mark and Osmaston; 2008). In these areas high summit elevations and a very wet climate produced some of the largest ice caps in Africa. However, climatically and geographically, the Atlas Mountains have more in common with the Mediterranean mountains. Plateau ice fields of similar size to these in the High Atlas have been reported from the Serra da Estrela in Portugal (Vieira 2008), c. $1000 \mathrm{~km}$ to the north, and this is the nearest place to Morocco that similar former ice masses have been reported. It is possible that plateau ice fields formed elsewhere in the Atlas Mountains, but little is known concerning the details of the glacial geomorphology beyond the Toubkal Massif. The M'Goun and Ayachi Massifs, c. $150 \mathrm{~km}$ and $400 \mathrm{~km}$ to the eastnortheast of Toubkal, repectively, are characterised by very clear and well-developed cirques (Wiche 1953; Awad, 1963). It is unlikely that plateau ice fields developed here despite their altitude (4071 $\mathrm{m}$ and $3747 \mathrm{~m}$ a.s.1., repectively). The is no literature on other significant central and eastern High Atlas massifs such as the Jebel Anghomar (3610 m a.s.1.) and Jebel Azurki (3677 m a.s.1.). Similarly, nothing is known from the western High Atlas, such as on Igdat (3615 $\mathrm{m}$ a.s.1.). A highelevation basin ( $>2500 \mathrm{~m}$ a.s.l.) is present in the Tichka Plateau in the westernmost Atlas. However, this is well below the altitudes of Iouzagner and Tazaghart. Plateau ice fields comparable to these areas would require plateau surfaces at $>3000 \mathrm{~m}$ a.s.1., which experience comparable climates. The Middle Atlas may be different because this area is much wetter that 
the High Atlas and it is possible that ice fields formed on lower plateau surfaces. However, very little is known of the glacial geomorphology from the Middle Atlas except for prelimiary observations by Awad (1963). In the Djurdjura Massif of Algeria, where the highest peak reaches just $2328 \mathrm{~m}$ a.s.l., glaciers are known to have extended as low as $750 \mathrm{~m}$ and $1250 \mathrm{~m}$ a.s.l. on the northern and southern slopes, respectively (Barbier and Cailleux 1950). Preliminary observations using satellite imagery reinforce this observation and also provide indications that this area also supported plateau ice fields. However, further fieldwork is needed in the Djurdjura in order to test this hypothesis further.

The climatic significance of plateau ice fields in the High Atlas is obvious. Combinations of both colder and wetter conditions would have favoured glacier expansion with wetter conditions offsetting the increased melting associated with smaller temperature depressions (Table 5). This is likely during African Humid Periods when the West African Monsoon expanded its range northwards over the current Saharan region. This last occurred between 14.8 and $5.5 \mathrm{ka}$ (DeMenocal 2000; Renssen et al. 2006). It is within this interval that the Phase III glaciers formed, which also coincided with the cooling episode of the Younger Dryas Chronozone (12.9-11.7 ka), although this interval was more arid than the overall humid phase between 14.8 and $5.5 \mathrm{ka}$ (DeMenocal 2000). An expanded West African Monsoon is known to have reached at least as far as $23^{\circ} \mathrm{N}$ during the last African Humid Period (Claussen et al. 1999), but the evidence for its effects north of this are unclear. Furthermore, monsoonal precipitation in summer may not have been conducive to positive glacier mass balance if it fell as rain. However, summer precipitation as snow is known to be important for glacier mass balance in the Himalaya (Baral et al. 2014), so this seasonal distribution cannot be discounted for the High Atlas, especially under colder Pleistocene temperatures. However, it is also likely that westerly influences would have also been important during humid periods, with evidence for increased prevalence of Atlantic depressions tracking through Morocco at these times (Luetscher et al. 2015). The relative contribution of southern monsoon-derived precipitation versus westerly Atlantic-derived precipitation for the development of glaciers in the High Atlas is still an open question. Despite the clear implications for changing precipitation regimes in North Africa during the late Quaternary, the role of precipitation should not outweigh the role of temperatures when considering the glacier records. For example, the Phase II glaciers appear to have formed close in time to the global LGM when there was no Africa Humid Period and when climate globally would have been drier. These conditions have been shown to be less favourable for glaciers in many areas around the globe (e.g. Hughes et al. 2013) despite this interval experiencing the coldest conditions of the last cold stage. The fact that glaciers were stable and formed significant moraines in Morocco means that their existence must have been driven by very cold conditions, with mean annual temperatures at least $7-8^{\circ} \mathrm{C}$ colder than today in order to sustain glaciers under precipitation at least as high as today.

There have been major advances in understanding the glacial history of the Atlas Mountains in recent years. However, large swathes of the Atlas Mountains remain unexplored in terms of glacial geomorphology. Glacier extents are simply unknown for most massifs and basic geomorphological observations are still required (e.g. the pioneer phase as defined in Hughes et al. 2006). This study goes beyond this and presents detailed geomorphological observations, the mapping phase, and by correlation with other studies nearby makes some progress towards an advanced phase, defined by Hughes et al. (2006, p. 335) as "characterised by detailed understanding of the geochronology of glacial sequences using radiometric dating alongside detailed sedimentological and stratigraphical analyses". Understanding the glacial history of the Atlas Mountains is important for establishing the 
climatic history of North Africa and major geomorphological features such as the Sahara Desert. Future work should focus on 1) mapping the extent of glaciations, 2) ordering, subdividing and dating the glacial sequences, and 3) developing glacier-climate models that can simulate cold-stage climates along transects across the Atlas. In addition to developing understanding of the glacial record, there is huge scope to link glacier and downstream fluvial records (e.g. Woodward et al. 2008) and also understand the relationship between glaciation and paraglacial landscape development, especially with regard to major mass movements in glaciated areas (e.g. Hughes et al. 2014). Given the scale of glaciation in the Tazaghart and Iouzagner areas, it is arguable that glaciers have been one of the most significant geomorphological agents in the Quaternary evolution of the High Atlas. Whilst tectonic activity, fluvial and slope processes are clearly also important for landscape evolution in the High Atlas (e.g. Babault et al. 2012; Delcaillau et al. 2010; 2011; Stokes et al. 2008), these are closely intertwined with glaciation and associated periglacial processes (e.g. Couvreur 1966). Glacial erosion affects uplift patterns in mountain chains (Tomkin and Braun 2002), shapes drainage morphometry (Amerson et al. 2008) and, consequently, directly influences post-glacial fluvial and slope processes (Dadson and Church 2005).

\section{Conclusions}

Plateau ice fields formed on the Tazaghart and Iouzagner plateaux in the High Atlas during the Pleistocene. Four moraine units indicate four phases of successively smaller glaciations. Soil profile development index results show that these surfaces are widely separated in time. Based on correlations with dated moraine sequences in the Toubkal and Aksoual areas (Hughes et al. 2011a; 2011b; 2012; Fink et al. 2012; 2014), the plateau ice fields and associated outlet glaciers are likely to pre-date the global LGM. A series of younger moraines units correlate with those in the Aksoual and Toubkal areas dating from the LGM and the Younger Dryas. The northern cliffs of the Tazaghart also support a unique feature, the only perennial snowpatch in the Atlas Mountains, which is marked and named on some topographic maps as 'névé permanent'. The permanence of this feature is in doubt today but moraines enclosing the area support no surface soils and are likely to date from the Little Ice Age and possibly even the 20th century. The evidence from Tazaghart and Iouzagner provides unique evidence for both the first Late Pleistocene plateau ice fields to be recognised in North Africa and also the region's first reported evidence of recent glacier activity.

\section{Acknowledgements}

George Hannah thanks Drs P. Friend and A.G. Smith for their advice during the execution of this research. We thank the two reviewers and the Editor, Jamie Woodward, for their detailed comments which helped improve this paper. This research was partly funded by the Royal Geographical Society (with IBG) Fieldcentre Grant and Thesiger-Oman Fellowship to Philip Hughes. We thank the Kasbah du Toubkal, Dar Imlil and Gîte Tamatert for their support and hospitality during the research and Graham Bowden (University of Manchester) who drew the figures.

\section{References}

Adamson, K.R., Woodward, J.C., Hughes, P.D., 2014. Pleistocene glaciofluvial sediment 
flux and catchment decoupling in a Mediterranean mountain karst. Quaternary Science Reviews 94, 28-43.

Alaoui Mdaghri, D., Guerraoui, A., Bensaïd, M., Dahmani, M., 1996. Carte Géologique du Maroc 1/100 000, Amizmiz. Feuille NH-29-XXII-2. Editions du Service Géologique du Maroc. Notes et Mémoires No. 371 (1996).

Amerson, B.E., Montgomery, D.R., Meyer, G., 2007. Relative size of fluvial and glaciated valleys in central Idaho. Geomorphology 93, 637-647.

Awad, H., 1963. Some aspects of the geomorphology of Morocco related to the Quaternary climate. The Geographical Journal 129, 129-139.

Babault, J., Van Den Driessche, J., Teixell, A., 2012. Longitudinal to transverse drainage evolution in the High Atlas (Morocco): the role of tectonics. Tectonics 31, TC4020, 15 pp.

Ballantyne, C.K., Benn, D.I., 1994. Glaciological constraints on protalus rampart development. Permafrost and Periglacial Processes 5, 145-53.

Baral, P., Kayastha, R.B., Immerzeel, W.W., Pradhananga, N.S., Bhattarai, B.C., Shahi, S., Galos, S., Springer, C., Joshi, S.P., Mool, P.K., 2014. Preliminary results of mass-balance observations of Yala Glaciers and analysis of temperature and precipitation gradients in Langtang Valley, Nepal. Annals of Glaciology 55, 9-14.

Barbier, A., Cailleux, A., 1950. Glaciare et périglaciaire dans le Djurdjura occidental (Algérie). Comptes Rendus des Séances de l'Académie des Sciences, Paris. Juillet-Décembre $1950,365-366$.

Bengtsson, L., Enell, M., 1986. Chemical analysis. In: Berglund, B.E. (Ed.) Handbook of Holocene palaecology and palaeohydrology. John Wiley \& Sons: London. p. 422-451.

Benn, D.I., 2004. Clast morphology. In Evans, D.J.A. and Benn, D.I. (Eds) A practical guide to the study of glacial sediments. Arnold: London. p. 78-92.

Benn, D.I., 2007. Clast form analysis. In: Elias, S.A. (Ed.) Encyclopedia of Quaternary Science. Elsevier: Amsterdam. p. 904-909.

Benn, D.I., Hulton, N.R.J., 2010. An Excel ${ }^{\mathrm{TM}}$ spreadsheet program for reconstructing the surface profile of former mountain glaciers and ice caps. Computers and Geosciences 36, 605-610.

Benn, D.I., Ballantyne, C.K., 1994. Reconstructing the transport history of glacigenic sediments: a new approach based on the co-variance of clast form indices. Sedimentary Geology 91, 215-227.

Benn, D.I., Evans, D.J.A. 1998. Glaciers and Glaciation. Arnold. 734 pp.

Birkeland, P.W., 1999. Soils and Geomorphology. Oxford University Press: New York. $3^{\text {rd }}$ Edition. 
Boulton, G.S., 1978. Boulder shapes and grain-size distributions of debris as indicators of transport paths through a glacier and till genesis. Sedimentology 25, 773-799.

Braithwaite, R.J., 2008. Temperature and precipitation climate at the equilibrium-line altitude of glaciers expressed by the degree-day factor for melting snow. Journal of Glaciology 54, 437-444.

Braithwaite, R.J., Raper, S.C.B., 2007. Glaciological conditions in seven contrasting regions estimated with the degree-day model. Annals of Glaciology 46 (1), 297-302.

Braithwaite, R.J., Raper, S.C.B. 2009. Estimating equilibrium-line altitude (ELA) from glacier inventory data. Annals of Glaciology 50 (53), 127-132.

Büdel, J. 1960. Die Frostschott-zone Südost Spitzbergen. Colloquium Geographica, 6, 105 pp.

Célerier, J., Charton, A., 1922. Sur la présence de formes glaciaires dans le Haut Atlas de Marrakech: Hespéris 2, 373-384.

Chardon,M., Riser, J., 1981. Formes et processus géomorphologiques dans le Haut-Atlas marocain. Revue de Géographie Alpine 69, 561-582.

Christiansen, H.H., 1998. 'Little Ice Age' nivation activity in northeast Greenland. The Holocene 8, 719-728.

Clark, D.H., Clark, M.M., Gillespie, A.R., 1994. Debris-covered glaciers in the Sierra Nevada, California, and their implications for snowline reconstructions. Quaternary Research 41, 139-153.

Claussen, M., Kubatzki, C., Brovkin, V., Ganopolski, A., 1998. Simulation of an abrupt change in Saharan vegetation in the mid-Holocene. Geophysical Research Letters 26, 20372040 .

Couvreur, G., 1966. Les formations périglaciares du Haut Atlas central Marocaine. Revue de Géographie du Maroc 10, 47-50.

Dadson, S., Church, M., 2005. Postglacial topographic evolution of glaciated valleys: a stochastic landscape evolution model. Earth Surface Processes and Landforms 30, 13871403.

Dean, W.E. 1974. Determination of carbonate and organic matter in calcareous sediments and sedimentary rocks by loss on ignition: comparison with other methods. Journal of Sedimentary Petrology 44, 242-248.

Delcaillau, B., Lavilee, E., Amhrar, M., Namous, M., Dugué, O., Pedoja, K., 2010. Quaternary evolution of the Marrakech High Atlas and morphotectonic evidence of activity along the Tizi N'Test Fault, Morocco. Geomorphology 118, 262-279. 
Delcaillau, B., Amrhar, M., Namous, M., Laville, E., Pedoja, K., Dugué, O., 2011.

Tranpressional tectonics in the Marrakech High Atlas : Insight by the geomorphic evolution of drainage basins. Geomorphology 134, 344-362.

De Martonne, E.,1924. Les formes glaciaires sur le versant Nord du Haut Atlas: Annales de Géographie (Paris, 15 Mai 1924), v. 183, p. 296-302.

deMenocal, P., Ortiz, J., Guilderson, T., Adkins, J., Sarnthein, M., Baker, L., Yarusinsky, M., 2000. Abrupt onset and termination of the Africa Humid period: rapid climate responses to gradual insolation forcing. Quaternary Science Reviews 19, 347-361.

Dresch, J., 1941. Recherches sur l'évolution du relief dans le Massif Central du Grand Atlas le Haouz et le Sous: Arrault et Cie, Maitres Imprimeurs. Tours. 653 pp.

Evans, I.S. 2007. Glacial landforms, erosional features. In: Elias, S.A. (Ed.) Encyclopedia of Quaternary Science. Amsterdam: Elsevier. p. 838-852.

Evans, D.J.A., Rea, B.R., Hansom, J.D., Whalley, W.B., 2002. Geomorphology and style of plateau icefield deglaciation in fjord terrains: the example of troms-Finnmark, north Norway. Jourbnal of Quaternary Science 17, 221-239.

Eyles, N., Rogerson, R.J., 1978. A framework for the investigation of medial moraine formation: Austerdalsbreen, Norway, and berendon Glacier, British Columbia, Canada. Journal of Glaciology 20, 99-113.

Fink, D., Hughes P., Fenton, C., 2012. Extent, timing and palaeoclimatic significance of glaciation in the High Atlas, Morocco. $21^{\text {st }}$ International Radiocarbon Conference, Paris, July 2012. Abstract Booklet, Abstract S18-P-348, p. 558, http://www.radiocarbon.org/Info/RC_2012_ABSTRACTS_BOOK.pdf

Fink, D., Hughes P., Fenton, C., 2014. A first ${ }^{10}$ Be cosmogenic glacial chronology from the High Atlas, Morocco, during the last glacial cycle. Geophysical Research Abstracts Vol. 16, EGU2014-1931, 2014.

Giraudi, C., Bodrato, G., Ricci Lucchi, M., Cipriani, N., Villa, I.M. Giaccio, B., Zuppi, G.M., 2011. Middle and Late Pleistocene glaciations in the Campo Felice Basin (central Apennines. Italy). Quaternary Research 75, 219-230.

Gomez, B., Small, R.J., 1985. Medial moraines of the Haut Glacier d'Arolla, Valais, Switzerland: debris supply and implications for moraine formation. Journal of Glaciology 31 , 303-307.

Grunewald K., Scheithauer J., 2010. Europe's southernmost glaciers: response and adaptation to climate change. Journal of Glaciology 42, 3-18.

Hambrey, M.J., Bennett, M.R., Dowdeswell, J.A., Glasser, N.F., Huddart, D., 1999. Debris entrainment and transfer in polythermal valley glaciers. Journal of Glaciology 45, 69-86.

Hannah, G., 2014. Quaternary glacial history of the Toubkal massif, High Atlas, North Africa. M.Phil thesis. March 2014. Corpus Christi College, University of Cambridge. 145 pp. 
Harbor, J. M., 1992. Numerical modelling of the development of U-shaped valleys by glacial erosion. Geological Society of America Bulletin 104, 1364-1375.

Harden, J.W., 1982. A Quantitative Index of Soil Development From Field Descriptions: Examples from a Chronosequence in Central California. Geoderma 28, 1-28.

Hawkins, F., 1985. Equilibrium-line altitudes and palaeoenvironments in the Merchants Bay area, Baffin Island, NWT, Canada. Journal of Glaciology 31, 205-213.

Heybrock, W., 1953. Eiszeitliche Gletscherspuren und heutige Schneeverhältnisse im Zentralgebiet des Hohen Atlas. Zeitschrift für Gletscherkunde und Glazialgeologie, 2, 317 321.

Hooker, J.D., Ball, J., 1878. Journal of a tour in Marocco and the Great Atlas, with an appendix including a sketch of the geology of Marocco, by George Maw. Macmillan \& Co. London. 499 pp.

Hughes, P.D., 2004. Quaternary glaciation in the Pindus Mountains, Northwest Greece. PhD thesis. University of Cambridge. $341 \mathrm{pp}$.

Hughes, P.D., 2010. Little Ice Age glaciers in Balkans: low altitude glaciation enabled by cooler temperatures and local topoclimatic controls. Earth Surface Processes and Landforms $35,229-241$.

Hughes, P.D., 2009. Twenty-first Century Glaciers in the Prokletije Mountains, Albania. Arctic, Antarctic and Alpine Research 41, 455-459.

Hughes, P.D., 2014. Little Ice Age glaciers in the Mediterranean mountains. Mediterranée $122,45-61$.

Hughes, P.D., Gibbard, P.L., Woodward, J.C., 2004. Quaternary glaciation in the Atlas Mountains, North Africa. In: Ehlers, J. and Gibbard, P.L. (Eds) Quaternary Glaciation Extent and Chronology. Volume 3: Asia, Latin America, Africa, Australia, Antarctica. Amsterdam: Elsevier. p. 255-260.

Hughes, P.D., Woodward, J.C., Gibbard, P.L., Macklin, M.G., Gilmour, M.A., Smith G.R., 2006. The glacial history of the Pindus Mountains, Greece. Journal of Geology 114, 413-434.

Hughes, P.D., Woodward, J.C., Gibbard, P.L., 2007. Middle Pleistocene cold stage climates in the Mediterranean: New evidence from the glacial record. Earth and Planetary Science Letters 253, 50-56.

Hughes, P.D., Woodward, J.C., van Calsteren, P.C., Thomas, L.E., Adamson, K., 2010. Pleistocene ice caps on the coastal mountains of the Adriatic Sea: palaeoclimatic and wider palaeoenvironmental implications. Quaternary Science Reviews 29, 3690-3708.

Hughes, P.D., Fenton, C.R., Gibbard, P.L., 2011a. Quaternary glaciations of the Atlas Mountains, North Africa. In: Ehlers, J., Gibbard, P.L. and Hughes, P.D. (Eds) Quaternary 
Glaciations - Extent and Chronology, Part IV - A Closer Look. Amsterdam: Elsevier. p. 1071-1080.

Hughes, P.D., Fenton, C.R., Fink, D., Schnabel, C., Rother, H., 2011b. Extent, timing and palaeoclimatic significance of glaciation in the High Atlas, Morocco. XVIII INQUA Congress, Bern, Switzerland, 21-27 July 2011. Abstract 864.

Hughes, P.D., Fenton, C.R., Fink, D., Schnabel, C., Rother, H. 2012. Extent, timing and palaeoclimatic significance of glaciation in the High Atlas, Morocco. Quaternary International 279-280, 210.

Hughes, P.D., Gibbard, P.L., Ehlers, J. 2013. Timing of glaciation during the last glacial cycle: evaluating the meaning and significance of the 'Last Glacial Maximum' (LGM). Earth Science Reviews 125, 171-198.

Hughes, P.D., Fink, D., Fletcher, W.J., Hannah, G. 2014. Catastrophic rock avalanches in a glaciated valley of the High Atlas, Morocco: ${ }^{10} \mathrm{Be}$ exposure ages reveal a $4.5 \mathrm{ka}$ seismic event. Geological Society of America Bulletin 126, 1093-1104.

Hughes, P.D., Gibbard, P.L. 2015. A stratigraphical basis for the Last Glacial Maximum (LGM). Quaternary International 383, 174-185.

Isarin, R.F.B., Renssen, H., Vandenberghe, J. 1998. The impact of the North Atlantic Ocean on the Younger Dryas climate in northwestern and central Europe. Journal of Quaternary Science 13, 447-453.

Kleman, J., 1994. Preservation of landforms under ice sheets and ice caps. Geomorphology 9, $19-32$.

Lefèvre, D. and Raynal, J-P., 2002. Les Formations Plio-Pléistocènes de Casablanca et la Chronostratigraphie du Quaternaire Marin du Maroc Revistées. Quaternaire 13, 9-21.

Luetscher, M., Boch, R., Sodemann, H., Spötl, C., Cheng, H., Edwards, R.L., Friscia, S., Hof, F., Müller, W., 2015. North Atlantic storm track changes during the Last Glacial maximum recorded by Alpine speleothems. Nature Communications 6, 6344. doi:10.1038/ncomms7344

Mark, B.G., Osmaston, H.A., 2008. Quaternary glaciation in Africa: key chronologies and climatic implications. Journal of Quaternary Science 23, 589-608.

McDougall, D.A., 2001. The geomorphological impact of Loch Lomond (Younger Dryas) Stadial plateau icefields in the central Lake District, northwest England. Journal of Quaternary Science 16, 531-543.

Meier, M.F., Post, A.S., 1962. Recent variations in mass net budgets of glaciers in western North America. International Association of Hydrological Sciences Publication 58, 63-77.

Mensching, H., 1953. Morphologische Studien im Hohen Atlas von Marokko. Würzburger Geographica Arbeiten, H.1, 104 pp. 
Messerli, B., 1967. Die eiszeitliche und die gegenwartige Vertgletscherung im Mittelemeeraum. Geographica Helvetica, 22, 105-228.

Müller, F., 1980. Present and late Pleistocene equilibrium line altitudes in the Mt Everest region - an application of the glacier inventory. International Association of Hydrological Sciences Publication, 126, 75-94.

Nye, J.F., 1952. A method for calculating the thickness of ice sheets. Nature 169, 529-530.

Orientazion, 2006. Toubkal \& Marrakech, Hiking Map, 1;50,000. Orientazion (later edition in 2008 published by Cordee)

Osmaston, H., 2002. Chapter 9. The nature, extents and climates of former Quaternary tropical glaciers, with reference to the East African Mountains. In Kaser, G. and Osmaston, H. (eds) Tropical Glaciers. Cambridge University Press: Cambridge. p. 149-192.

Osmaston, H., Harrison, S.P., 2005. The Late Quaternary glaciation of Africa: A regional synthesis. Quaternary International 138-139, 32-54.

Pellitero, R., Rea, B., Spagnolo, M., Bakke, J., Hughes, P.D., Ivy-Ochs, S., Lukas, S., Ribolini, A., 2015. A GIS tool for automatic calculation of glacier Equilibrium Line Altitudes. Computers and Geosciences 82, 55-62.

Porter, S.C., 1975. Equilibrium-line altitudes of late Quaternary glaciers in the Southern Alps, New Zealand. Quaternary Research 5, 27-47.

Rea, B. 2009. Defining moden day Area-Altitude Balance Ratios (AABRs) and their use in glacier-climate reconstructions. Quaternary Science Reviews 28, 237-248.

Rea, B.R., Evans, D.J.A., 2003. Plateau icefield landsystems. In: Evans, D.J.A. (Ed.) Glacial Landsystems. Hodder Arnold, London. p. 407-431.

Rea, B.R., Evans, D.J.A. 2007. Quantifying climate and glacier mass balance in north Norway during the Younger Dryas. Palaeogeography, Palaeoclimatology, Palaeoecology 246, 307-330.

Rea, B.R., Whalley, W.B., Dixon, T.S., Gordon, J.E., 1999. Plateau icefields as contributing area to valley glaciers and gthe potential impact on reconstructed ELAs: a case study from the Lyngen Alps, North Norway. Annals of Glaciology 28, 97-102.

Renssen, H., Brovkin, V., Fichefet, T., Goosse, H., 2006. Simulation of the Holocene climate evoultion in Northern Africa: The termination of the African Humid Period. Quaternary International 150, 95-102.

Robinson, D.A., Williams, R.B.G., 1992. Sandstone weathering in the High Atlas, Morocco. Zeischrift für Geomorphologie 36, 413-429.

Saadi, S.E.M., Hilali, E.A., Boudda, A., 1978. Carte Géologique du Maroc 1/500 000 Feuille Marrakech. Editions du Service Géologique du Maroc, (1957). Notes et Mémoires 70 (Réimpression en 1978). 
Schilling, D.H., Hollin, J.T., 1981. Numerical reconstructions of valley glaciers and small ice caps. In: Denton, G.H., Hughes, T.J. (Eds.), The Last Great Ice Sheets. Wiley, New York. p. 207-220.

Schomaker, A. 2011. Moraine. In: Singh, V.P., Singh, P., Haritashya, U.K., (Eds.)

Encyclopedia of Snow, Ice and Glaciers. Springer: Dordrecht, Netherlands. P. 747-755.

Smith, K., 2004. Trekking in the Atlas Mountains. Cicerone Press. 160 pp.

Spedding, N., Evans, D.J.A., 2002. Sediments and landforms at Kviárjökull, southeast Iceland: a reappraisal of the glaciated valley landsystem. Sedimentary Geology 149, 21-42.

Stokes, M., Mather, A.E., Belfoul, A., Farik, F. 2008. Active and passive tectonic controls for transverse drainage and river gorge development in a collisional mountain belt (Dades Gorges, High Atlas Mountains, Morocco). Geomorphology 102, 2-20.

Thompson, J. 1899. The Geology of Southern Morocco and the Atlas Mountains. Quarterly Journal of the Geological Society 55, 190-213.

Tomkin, J.H., Braun, J., 2002. The influence of alpine glaciation on the relief of tectonically active mountain belts. American Journal of Science 302, 169-190.

US Army Map Service 1943. Tahanout. Sheet 19. 1:125,000. Compiled from Service Géographique du Maroc 1:100,000, 1937 to 1940.

Vieira, G.T. 2008. Combined numerical and geomorphological reconstruction of the Serra da estrela plateau icefield, Portugal. Geomorphology 97, 190-207.

Villa, E., Stoll, H., Farias, P., Adrados, L., Edwards, L., Cheng, H., 2013. Age and significance of the Quaternary cemented deposits of the Duje Valley (Picos de Europa, Northern Spain). Quaternary Research 79, 1-5.

Werner, B.T., Hallet, B., 1993. Numerical simulation of self-organised stone stripes. Nature $361,142-145$.

Wiche, K., 1953. Klimamorphologische und talgeschichtliche Studien im M'Goungebiet. Mitteilungen Der Geographischen Gesellschaft Wien 95, 4-41.

Woodward, J.C., Macklin, M.G., Lewin, J., 1994. Pedogenic weathering and relative-age dating of Quaternary alluvial sediments in the Pindus Mountains of northwest Greece. In: D.A. Robinson and R.B.G. Williams (eds) Rock Weathering and Landform Evolution. Chichester, John Wiley, 259-283.

Woodward, J.C., Hamlin, R.H.B., Macklin, M.G., Hughes, P.D., Lewin, J., 2008. Pleistocene catchment dynamics in the Mediterranean: glaciation, fluvial geomorphology and the slackwater sediment record. Geomorphology 101, 44-67.

World Meteorological Organisation, 1998. 1961-1990 global climate normals. Electronic resource. National Climatic Data Center, US: Asheville, NC. (CD-ROM). 
Žebre, M., Stepišnik, U., 2015, Glaciokarst landforms and processes of the Southern Dinaric Alps. Earth Surface Processes and Landforms. DOI: 10.1002/esp.3731 


\section{Figures}

Figure 1. Glacial geomorphological map of the Azzaden valley. The symbol for glaciallytransported boulders indicates widespread boulder accumulations and where these form ridges then they are mapped by the moraine symbol. The symbol for perched erratics indicates isolated large $(>1 \times 1 \times 1 \mathrm{~m})$ and prominent erratic boulders resting on bedrock of a different lithology. For a more detailed map of stratigraphical Unit 4, which shows S11 and 12, below the northern cliffs of Tazaghart see Figure 9.

Figure 2. Cross-sections of Azzaden and Timellite valleys. The locations of these crosssections are indicated in Figure 1. Each point represents the intersection of a contour on the 1:50,000 topographic map of the area. The cross-sections are fitted with a second-order polynomial (or quadratic) regression. This approach has been demonstarted to be the most appropriate for glacial trough cross-sections and represent the trendline that resemble a $\mathrm{U}$ shape (Walkenbach 2007).

Figure 3. Control sample for clast analysis from a scree slope in the Azzaden valley (located below the northern cliffs of Tazaghart). These clasts have not undergone subglacial active transport and can be compared with clasts which have (Figures 4 and 9 and Table 3 ).

Figure 4. Clast data from 6 sites in the lower Azzaden valley (see Figure 1 for locations)

Figure 5. The lowest and oldest moraines in the Azzaden Valley (Unit 1). Both photographs show moraine ridges with large boulders near Azib Ramsoult (see Figure 1 for location). Despite the large boulders the fine moraine matrix and the well-developed surface soils have been exploited for agriculture (see agricultural terraces)

Figure 6. Soil profile data for the Azzaden valley. These laboratory analyses supplement the field-derived profile development index data.

Figure 7. This is the Unit 2 moraine ridge in the Azzaden Valley. This is situated up-valley of ice-moulded bedrock (right centre) between 2600 and $2800 \mathrm{~m}$ a.s.l. Looking up-valley with the Tazaghart cliffs in the background. See Figure 1 for location.

Figure 8 . The Unit 3 moraines below the cliffs of Tazaghart. The top photograph shows the moraines in September 2012. The bottom photograph shows the same moraine in April 2013 with snow still present on the Tazaghart cliffs behind the moraine.

Figure 9. Geomorphological map of the 'névé permanent' \& clast data from the sediment ridge bounding this feature. The location of this site is indicated by stratigraphical Unit 4 in Figure 1 and the Phase IV glacier in Figure 15.

Figure 10. The névé permanent on the northern cliffs of the Tazaghart in September 2012. The bottom picture shows the lower part of the snow patch and the bounding sediment ridges. A person can be seen for scale on the far ridge in the centre of the photograph. Whilst the snow patch is semi-permanent today the sedimentology of the sediment ridges suggests that they were formed by a dynamic ice mass (i.e. a small niche glacier). The absence of soils suggests that these moraine ridges are relatively young. Topographic maps from the mid 20th Century suggest that the snow was permanent and it is likely that the moraines date from the 
last few hundred years, forming at the end of the Little Ice Age and possibly into the 20th Century.

Figure 11. Glacial geomorphological map of the western slopes of Tazaghart and Iouzagnar.

Figure 12. Moraine ridge on the eastern side of the Oussal Valley (looking NW at c. $2300 \mathrm{~m}$ a.s.1.). The moraine is dominated by volcanic boulders (derived from the upper catchment) with occasional limestone boulders (from the middle catchment), which are all erratics resting on schist bedrock in the lower part of the valley (April 2013).

Figure 13. Large erratic volcanic boulders resting on a limestone knoll at c. $2300 \mathrm{~m}$ a.s.l. in the Oussal Valley. These boulders are the remnants of the western lateral moraine of the Oussal Phase I glacier. The rocks up-valley of this narrow limestone bedrock band are volcanic. The limestone bedrock continues behind this moraine in the photograph and forms shattered tor-like features in contrast to the smooth limestone surface covered by the moraine. The example in this photograph is relatively small whereas in other valleys the tors reach up to $100 \mathrm{~m}$ above the the valley floor.

Figure 14. The Tazaghart Plateau. Looking NW from the eastern side of the plateau. Two people are visible for scale in the distant-left side of the photograph. The foreground shows the nature of the regolith on the plateau.

Figure 15. Glacier reconstructions showing the four glacier phases. Ice surface contours relate to the largest, Phase I, glaciation. Areas where glacier limits are uncertain are marked by question marks. East of the peaks of Akoiud, Afella and Biguinnoussene the area was glaciated by large glaciers near Toubkal, the highest peak in the Atlas Mountains, which is just off the map c. $2.5 \mathrm{~km}$ to the east.

Figure 16. Standard deviation of altitudes for the Phase I glaciers at different accumulation area ratios (AARs). 


\section{Tables}

Table 1. Climate data from Marrakech (484 m a.s.1.). From the World Meterological Organisation (1998) climate normals for 1961-1990.

\begin{tabular}{|l|l|l|l|l|l|l|l|l|l|l|l|l|l|}
\hline & J & F & M & A & M & J & J & A & S & O & N & D & $\begin{array}{l}\text { Annual } \\
\text { mean }\end{array}$ \\
\hline $\begin{array}{l}\text { Mean } \\
\text { monthly } \\
\text { temperature } \\
\left({ }^{\circ} \mathrm{C}\right)\end{array}$ & 12.2 & 13.8 & 15.8 & 17.3 & 20.6 & 23.8 & 28.3 & 28.3 & 25.3 & 21.1 & 16.3 & 12.6 & $\mathbf{1 9 . 6}$ \\
\hline $\begin{array}{l}\text { Precipitation } \\
(\mathrm{mm})\end{array}$ & 32.2 & 37.9 & 37.8 & 38.8 & 23.7 & 4.5 & 1.2 & 3.4 & 5.9 & 23.9 & 40.6 & 31.4 & $\mathbf{2 8 1 . 3}$ \\
\hline
\end{tabular}


Table 2. Soil profile development index (PDI) data from the Azzaden valley. See Figure 1 for profile locations. For detailed soil profile data see Hannah (2014).

\begin{tabular}{|l|l|l|l|}
\hline Moraine Unit & Soil profile site & $\begin{array}{l}\text { Profile development index } \\
\text { (PDI) }\end{array}$ & $\begin{array}{l}\text { Laboratory data } \\
\text { available }\end{array}$ \\
\hline 1 (oldest) & P1 & 24.02 & Yes - see Figure 6 \\
\hline 1 & P2 & 26.33 & No \\
\hline 2 & P3 & 14.26 & Yes - see Figure 6 \\
\hline 2 & P4 & 11.54 & No \\
\hline 3 & P5 & 2.29 & Yes - see Figure 6 \\
\hline 3 & P6 & 2.95 & No \\
\hline 4 & P7 & 0 & Yes - see Figure 6 \\
\hline 4 (youngest) & P8 & 0 & No \\
\hline
\end{tabular}


Table 3. Sediment data from the valleys on western slopes of Tazaghart and Iouzagner. The locations of the sample sites are shown in Figure 11.

\begin{tabular}{|l|l|l|l|l|}
\hline Sample Site & $\mathbf{C}_{\mathbf{4 0}}$ index & RA index & Roundness (\%) & Striated (\%) \\
\hline S15 (Tougdal) & 28 & 28 & VA:6; A:22; SA:42; SR:30 & 48 \\
\hline S16 (Tougdal) & 24 & 24 & VA:10; A:14; SA:44; SR:32 & 16 \\
\hline S17 (Tougdal, unit 2) & 30 & 18 & VA:8; A:10; SA:46; SR:36 & 24 \\
\hline S18 (Tougdal, unit 3) & 40 & 20 & VA:6; A:14; SA:35; SR:45 & 36 \\
\hline S19 (Tizgui) & 30 & 32 & VA:14; A:18; SA:40; SR:28 & 54 \\
\hline S20 (Amizmiz) & 24 & 30 & VA:6; A:24; SA:30; SR:40 & 30 \\
\hline S21 (Oussal) & 28 & 28 & VA:14; A:14; SA:40; SR:32 & 42 \\
\hline S22 (Ameslane) & 42 & 18 & VA:8; A:10; SA:46; SR:36 & 44 \\
\hline
\end{tabular}


Table 4. Area and ELA data for the glacier Phases I to III. See Figures 1 and 11 for valley locations.

\begin{tabular}{|l|l|l|l|}
\hline Glacier & Area $\left(\mathbf{k m}^{\mathbf{2}}\right)$ & ELA $(\mathbf{B R}=\mathbf{1 . 7 5}) \mathbf{( m )}$ & ELA (AAR $=\mathbf{0 . 5})(\mathbf{m})$ \\
\hline Phase I & & & \\
\hline Ameslane & 1.59 & 2681 & 2860 \\
\hline Oussal & 3.71 & 2921 & 3122 \\
\hline Amizmiz & 2.96 & 2609 & 2650 \\
\hline Tizgui & 2.08 & 2763 & 3020 \\
\hline Tougdal (1) & 1.15 & 2905 & 3138 \\
\hline Tougdal (2) & 6.57 & 2994 & 3262 \\
\hline Bouidarene & 0.91 & 2801 & 2916 \\
\hline Azzaden & 4.17 & 2981 & 3140 \\
\hline Timellite & 1.95 & 2806 & 2907 \\
\hline & Total area $=25.09$ & Mean $=2829$ & Mean $=3002$ \\
\hline Phase II & & & \\
\hline Tougdal & 0.66 & 2779 & 2815 \\
\hline Azzaden & 2.09 & 3305 & 3420 \\
\hline Timellite & 0.83 & 3330 & 3424 \\
\hline & Total area $=3.58$ & Mean $=3202$ & Mean $=3220$ \\
\hline Phase III & & & \\
\hline Tougdal & 0.38 & 2867 & 2892 \\
\hline Azzaden & 0.82 & 3358 & 3471 \\
\hline Timellite & 0.42 & 3475 & 3508 \\
\hline & Total area $=1.62$ & Mean $=3233$ & Mean $=3290$ \\
\hline & & & \\
\hline
\end{tabular}


Table 5. Glacier equilibrium line altitudes (ELAs; calculated using the median elevation of glacier surfaces $\sim$ AAR $=0.5$ ) and associated mean annual temperatures. The melting associated with these mean annual temperatures is shown along with the melt (in mm water equivalent) associated with step-wise depressions of temperature by $1{ }^{\circ} \mathrm{C}$. Today precipitation is c. $1000 \mathrm{~mm}$ in the highest mountains. The table shows that under similar precipitation conditions or drier conditions than today then temperatures must be depressed by large amounts in order to sustain glaciers. This modelling assumes the same annual temperature range as today. Higher annual ranges produce greater melt values because of higher summer temperatures.

\begin{tabular}{|c|c|c|c|c|c|c|c|c|}
\hline & Phase I & & Phase II & & Phase III & & Phase IV & \\
\hline ELA & $3002 \mathrm{~m}$ & & $3220 \mathrm{~m}$ & & $3290 \mathrm{~m}$ & & $3440 \mathrm{~m}$ & \\
\hline${ }^{\circ} \mathrm{C}$ Temp $\Delta$ from Marrakech (484 m) & 15.1 & Melt & 16.4 & melt & 16.8 & melt & 17.7 & melt \\
\hline $\mathrm{MAT}^{\circ} \mathrm{C}$ at ELA [today] & 4.5 & 7822 & 3.2 & 6540 & 2.8 & 6167 & 1.9 & 5366 \\
\hline MAT -1 & 3.5 & 6825 & 2.2 & 5628 & 1.8 & 5280 & 0.9 & 4534 \\
\hline-2 & 2.5 & 5895 & 1.2 & 4778 & 0.8 & 4454 & -0.1 & 3762 \\
\hline-3 & 1.5 & 5026 & 0.2 & 3987 & -0.2 & 3688 & -1.1 & 3049 \\
\hline-4 & 0.5 & 4218 & -0.8 & 3257 & -1.2 & 2981 & -2.1 & 2396 \\
\hline-5 & -0.5 & 3470 & -1.8 & 2585 & -2.2 & 2334 & -3.1 & 1804 \\
\hline-6 & -1.5 & 2780 & -2.8 & 1975 & -3.2 & 1748 & -4.1 & 1277 \\
\hline-7 & -2.5 & 2152 & -3.8 & 1428 & -4.2 & 1227 & -5.1 & 818 \\
\hline-8 & -3.5 & 1585 & -4.8 & 948 & -5.2 & 776 & -6.1 & 437 \\
\hline-9 & -4.5 & 1085 & -5.8 & 542 & -6.2 & 403 & -7.1 & 147 \\
\hline-10 & -5.5 & 656 & -6.8 & 223 & -7.2 & 125 & -8.1 & 0 \\
\hline-11 & -6.5 & 309 & -7.8 & 20 & -8.2 & 0 & -9.1 & 0 \\
\hline-12 & -7.5 & 65 & -8.8 & 0 & -9.2 & 0 & -10.1 & 0 \\
\hline
\end{tabular}



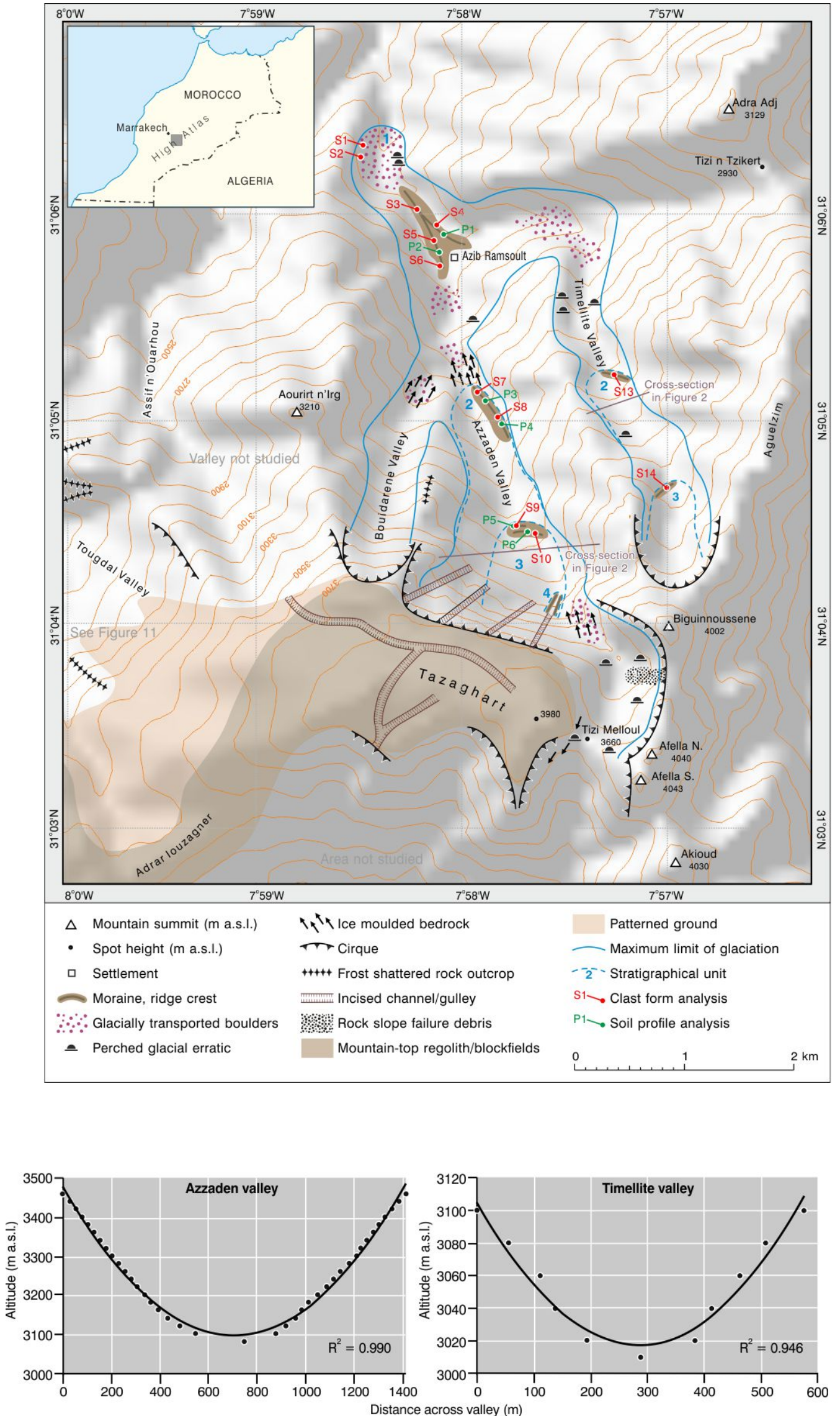

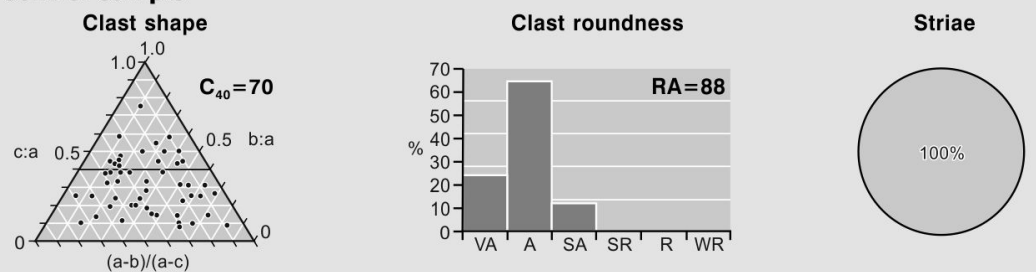

$>$ Present $\nabla$ Absent

\section{Sample 1 (S1)}
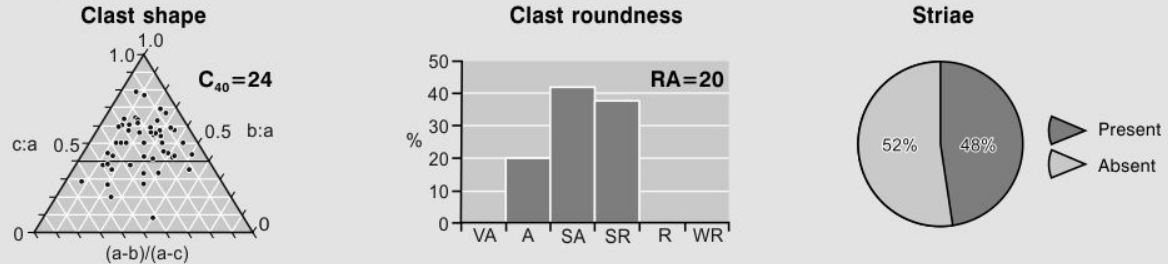

Sample 2 (S2)
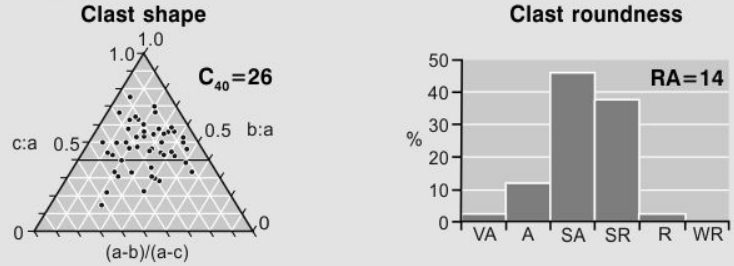

Striae

last shape
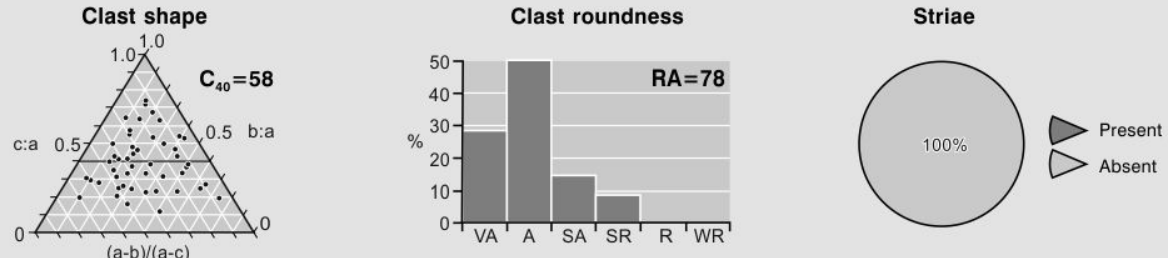

Sample 4 (S4)
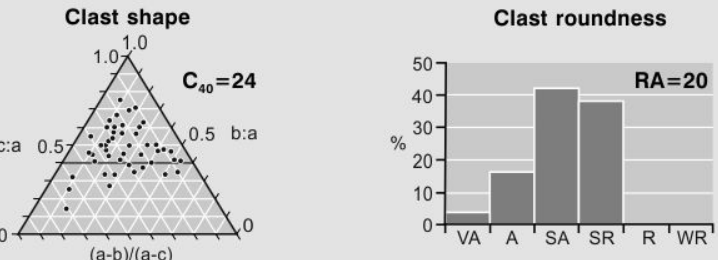

Striae

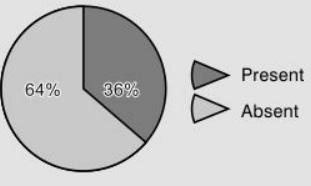

Sample 5 (S5)
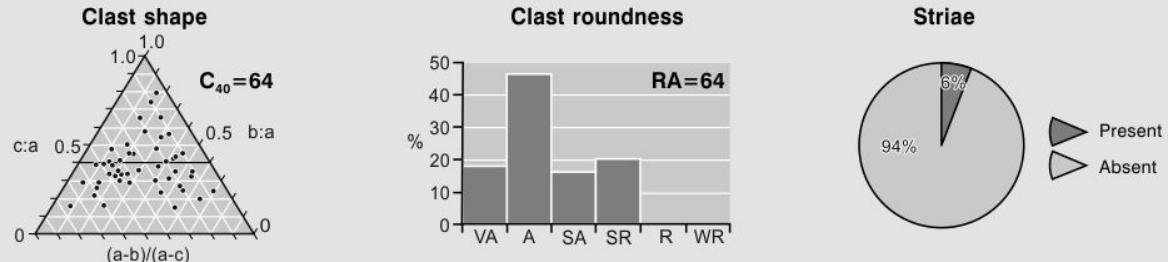

\section{Sample 6 (S6)}
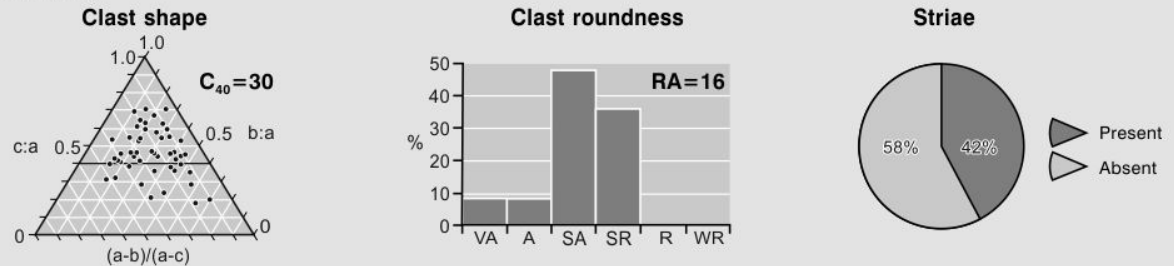

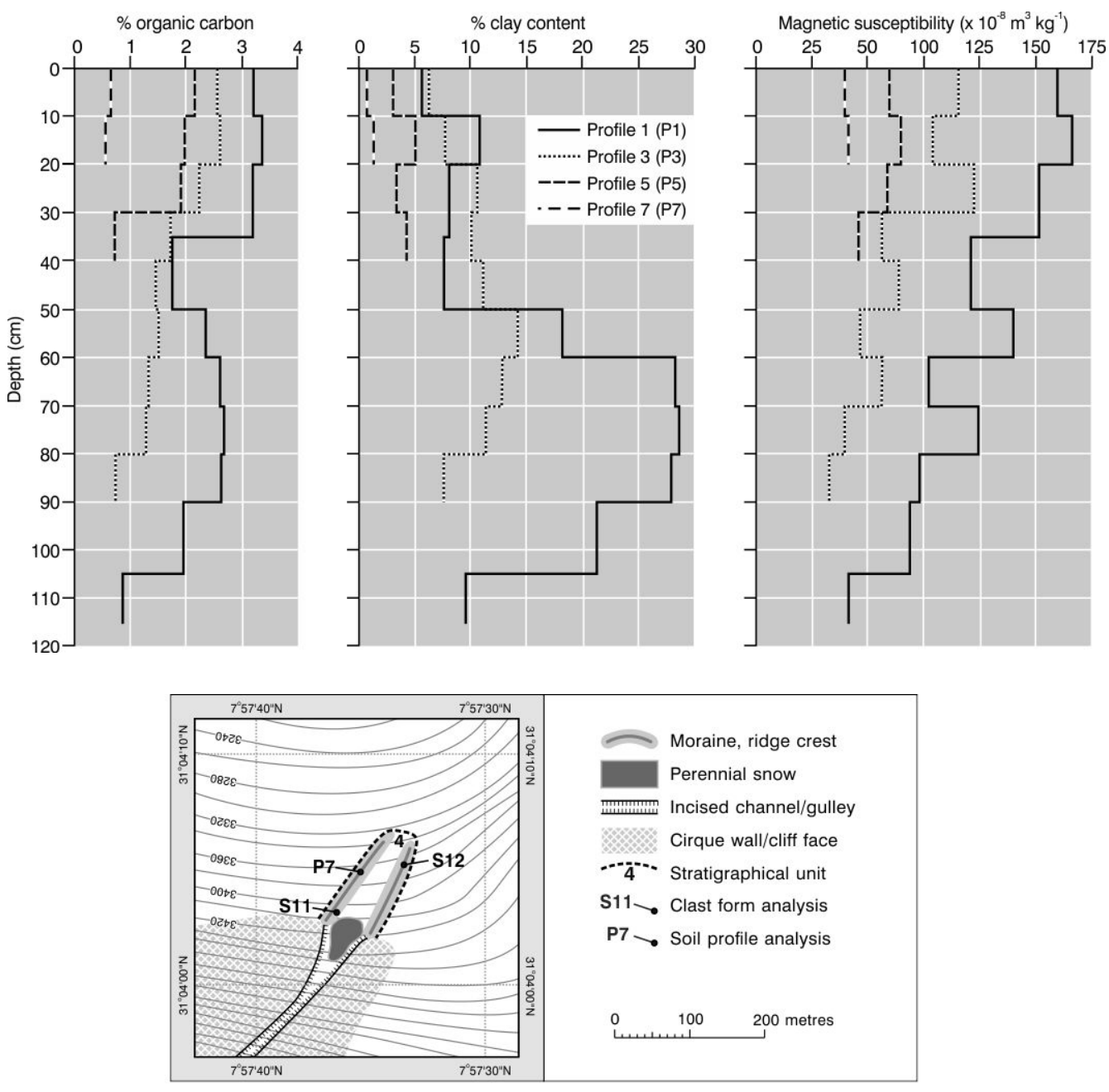

Sample 11 (S11)
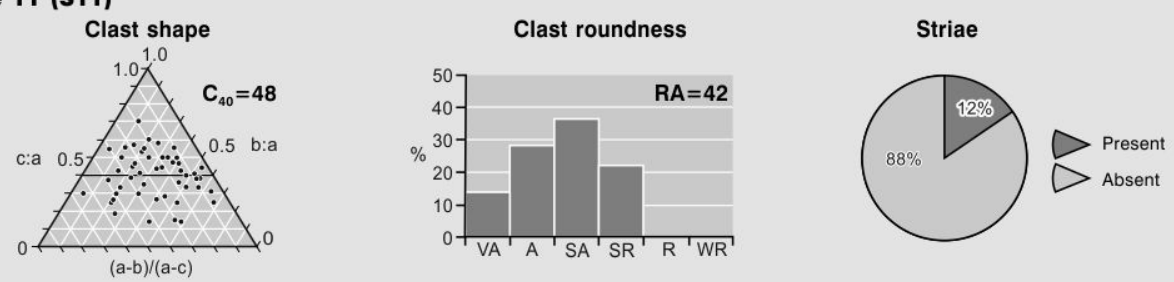

Sample 12 (S12)
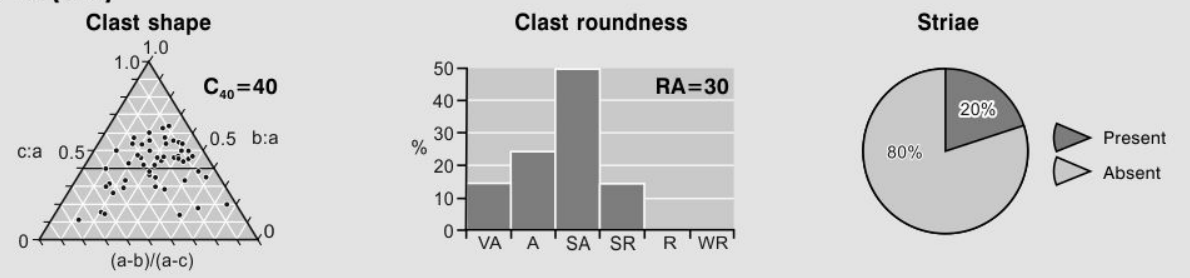

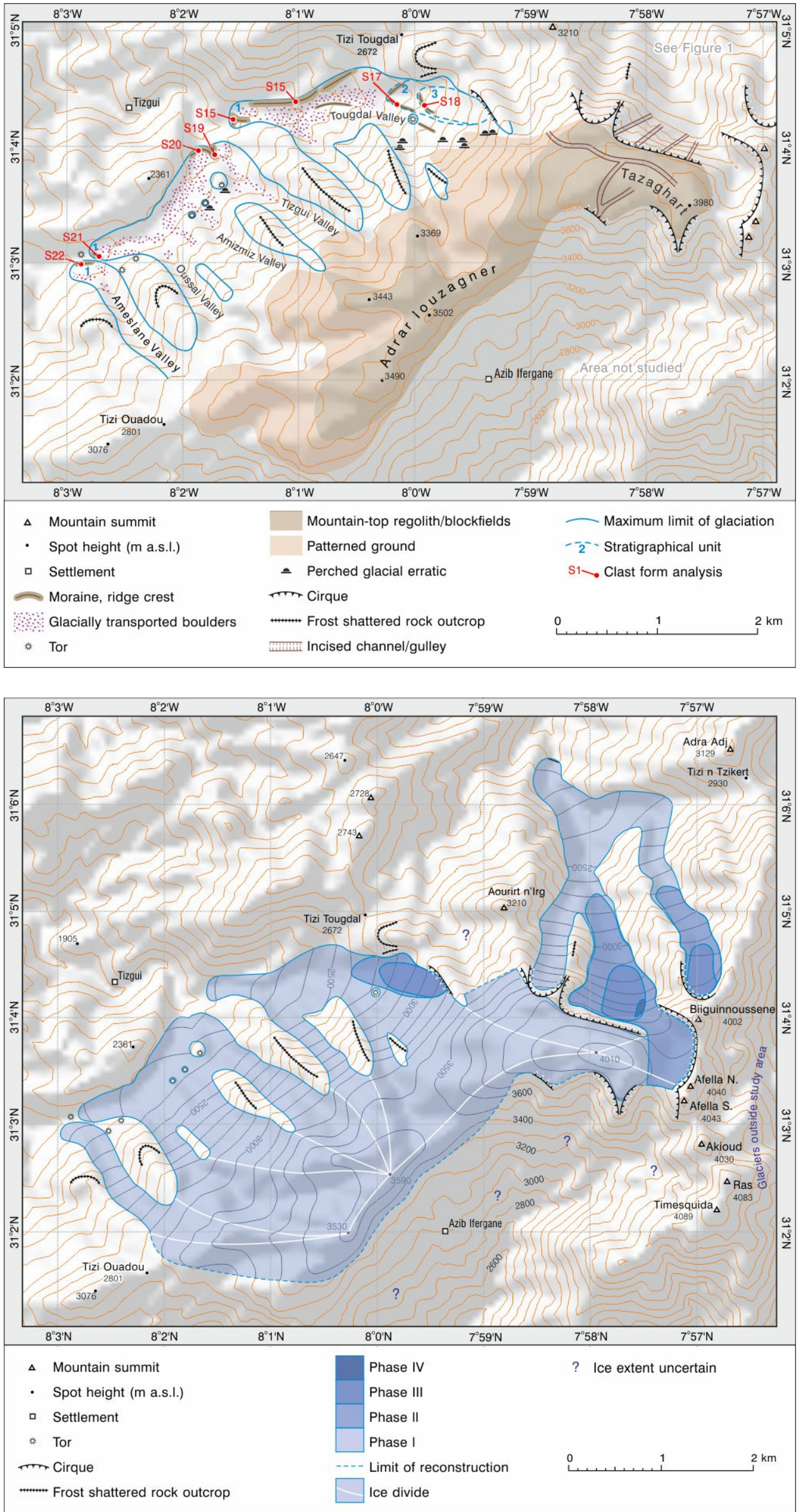


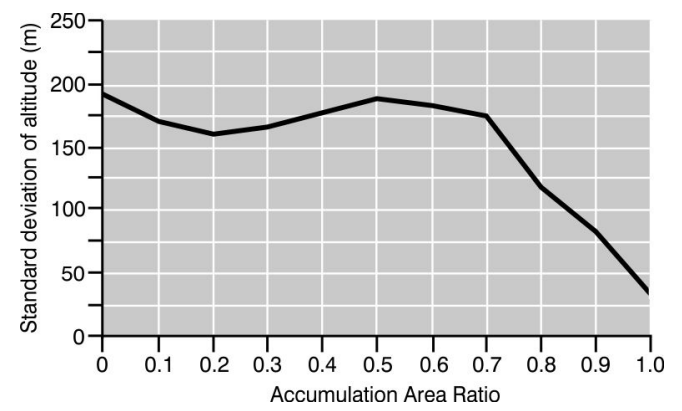

